\title{
Okul Öncesi Dönem Çocuklarının Değer Kavramlarını Tanımlamalarının İncelenmesi: Nitel Bir Çalışma
}

\section{Investigation of Preschool Children's Descriptions of Value Concepts: A Qualitative Study}

Nihat TOPAÇ, Sorumlu Yazar, Öğretim Görevlisi.

İstanbul Üniversitesi-Cerrahpaşa, Hasan Ali Yücel Eğitim Fakültesi, Türkiye.

ntopac@istanbul.edu.tr

https://orcid.org/0000-0001-9364-4072

Musa BARDAK, Öğretim Görevlisi.

İstanbul Sabahattin Zaim Üniversitesi, Eğitim Fakültesi, Türkiye.

musa.bardak@izu.edu.tr

https://orcid.org/0000-0001-5585-8002

Murat KIRIŞCi, Doç. Dr.

İstanbul Üniversitesi - Cerrahpaşa, Cerrahpaşa Tıp Fakültesi, Türkiye.

murat.kirisci@istanbul.edu.tr

https://orcid.org/0000-0003-4938-5207

Ercan MERTOĞLU, Dr. Öğr. Üyesi.

Marmara Üniversitesi, Atatürk Eğitim Fakültesi, Türkiye.

ercan.mertoglu@marmara.edu.tr

https://orcid.org/0000-0002-4614-7687

ISSN: 1303-880X

e-ISSN: 2667-7504

http://ded.dem.org.tr

Makale Türü / Article Type:

Araştırma Makalesi / Research Article

Geliş Tarihi / Received Date: 14.04.2020

Kabul Tarihi / Accepted Date: 11.06.2020

Yayın Tarihi / Published Date: 25.06.2020

\section{Tr/En: $\operatorname{Tr}$}

Intihal / Plagiarism: Bu makale, en az iki hakem tarafindan incelendi ve intihal içermediği teyit edildi. / This article has been reviewed by at least two referees and scanned via a plagiarism software.
Atıf/Citation: Topaç, N., Bardak, M., Kirişçi, M. \& Mertoğlu, E. (2020). Okul öncesi dönem çocuklarının değer kavramlarını tanımlamalarının incelenmesi: Nitel bir çalışma. Değerler Eğitimi Dergisi,18 (39), s.447-487. https://doi.org/10.34234/ded.720094 
Öz: Bu çalışma erken çocukluk dönemi çocuklarının çeşitli değer kavramlarını nasıl algıladıklarını ve tanımladıklarını araştırmak amacıyla yapılmıştır. Çalışmada nitel araştırma desenlerinden fenomenolojik yaklaşım kullanılmıştır. Araştırmanın çalışma grubunu okul öncesi eğitime devam eden 5 yaşındaki 20 çocuk oluşturmuştur. Çocuklar belirlenirken, amaçlı örnekleme yöntemlerinden tipik durum örneklemesi kullanılmıştır. Örneklemin tamamının aynı sosyo-ekonomik düzeyde ve daha önce formal değerler eğitimi almamış olmasına dikkat edilmiştir. Çocuklara araştırmacılar tarafından seçilen 7 değer kavramını içeren açık uçlu sorulardan (sorumluluk, paylaşma, yardımseverlik, arkadaşlık, saygı, dürüstlük ve nezaket) oluşan veri toplama aracı yarı yapılandırılmış görüşme tekniğiyle uygulanmıştır. Elde edilen veriler içerik analizi tekniği ile değerlendirilmiştir. Katılımcıların değer kavramlarıyla ilgili sorulara verdiği cevaplardan elde edilen veriler kodlanmış ve temalar oluşturularak tablolaştırılmıştır. Bulguların tanımlanıp yorumlanmasıyla elde edilen sonuçlarda çocukların sorumluluk, paylaşma, yardımseverlik ve saygı değerleri ile ilgili algılama ve tanımlamalarının birbirine benzer olduğu görülmüştür. Sorumluluk değerini tanımlarken çocukların genellikle evde kendilerine telkin edilen görevler üzerinden tanımlamalar yapmaya çalıştığı; paylaşma ve yardımseverlik değerlerine yönelik tanımlamalarda daha önce yaşamış oldukları paylaşma ve yardımlaşma deneyimlerinden etkilendikleri; saygı değerine ilişkin tanımlamalarında ise çevresindeki yetişkinlerin davranış ve öğretilerinden etkilendikleri görülmektedir. Arkadaşlık değerini ise paylaşma ve yardımseverlik değerleri üzerinden açıklamaya çalıştıkları saptanmıştır. Dürüstlük ve nezaket kavramlarının ise çoğunlukla algılanamayan ve tanımlanamayan kavramlar olduğu tespit edilmiştir.

Anahtar Kelimeler: Erken çocukluk eğitimi, Okul öncesi eğitim, Değerler eğitimi, Algılama, Tanımlama.

\section{\&}

Abstract: This study was conducted to investigate how early childhood children perceive and define various concepts of value. Phenomenology, which is one of the qualitative research patterns, was used in the study. The study group of the study consisted of 205 -year-old children who continue preschool education. While determining the children, a typical case sampling, which is one of the purposeful sampling methods, was used. It was noted that the entire sample was not educated in the same socio-economic level and planned value education before. A data collection tool that consist of open-ended questions with 7 value concepts (responsibility, sharing, benevolence, friendship, respect, hon- 
esty and courtesy), selected by researchers, was applied to the children with a semi-structured interview technique. The data obtained were evaluated by content analysis method. The data obtained from the answers given by the participants to the questions about value concepts were coded and themes were created and arranged in tables. In the results obtained by defining and interpreting the findings, it was seen that the perceptions and definitions of children of responsibility, sharing, benevolence and respect values are similar. In defining the value of responsibility, children often try to make definitions over the tasks that are assigned to them at home; in the definitions of sharing and benevolence values, they were influenced by the experiences of sharing and solidarity they had previously experienced; In their definitions of respect value, it is seen that they are affected by the behaviors and teachings of adults around them. As a result of the research, the answers given by the children to the questions about the value concepts were grouped. It has been observed that the perceptions and definitions of children about responsibility, sharing, benevolence and respect values are similar. It was seen that they tried to explain the value of friendship through sharing and benevolence values. It has been found that the concepts of honesty and kindness are the least perceived and undefined ones.

Keywords: Early childhood education, Preschool education, Values education, Perception, Definition.

(The Extended Abstract is at the end of the article)

\section{Giriş}

Değerler, toplumun en küçük parçası olan insanın yetişmesi ve şekillenmesinde önemli bir rol oynamaktadır. Althof ve Berkowitz (2006), Aristo ve Konfüçyüs'ün de içinde bulunduğu fillozofların, ahlak ve karakter kavramlarıyla ilgilenerek, bu alanların her ikisinin de merkezindeki sorulara derinlemesine cevap aradıklarını ifade ederek bu rolün altını çizmiştir. Araştırmacılar bu sorulardan bir tanesinin, 'çocukların ne tür bir insan olmasının istendiği ve onların bu şekilde nasıl yetiştirilip eğitilebileceği’ olduğunu da aktarmıştır. Buradan hareketle değerlerin, bireyin şekillenmesinde ve istenilen davranışları gerçekleştirmesinde kritik bir öneme sahip olduğu söylenebilir.

Değer kavramının tanımına ve etimolojisine ilişkin, ulusal ve uluslararası alanyazında çok sayıda çalışma bulunmaktadır. Bu kavramın, Latince kökenli 
bir kelime olduğunu kıymetli ya da güçlü olmak anlamına gelen "valare" sözcügünden türetildiğini belirten Bilgin (1995), bu kelimenin alanyazına Znaniecki tarafından kazandırıldığını aktarmaktadır. Williams'a (1979) göre değerler; insanın ilgi alanları, zevkleri, beğenileri, tercihleri, görevleri, ahlaki sorumlulukları, arzuları, istekleri, amaçları, ihtiyaçları, hoşlanmadığı şeyleri, konumları gibi başka birçok şeyi belirleyip karar vermesinde, farklı şekillerde kullandığ1 bir unsurdur. Rokeach'a (1979) göre değerler, insanın hayatını şekillendiren ve birçok temel davranışında etkin olan inançlardır. Halstead ve Taylor'a (2000) göre ise değerler; insanın davranışlarını yönlendiren ilkeleri ve temel inançları; belli davranışların iyi veya arzu edilebilir olup olmadığına karar verilmesini sağlayan standartlardır. Schwartz (1994) değerin, insanların ya da toplumların hayatına rehberlik ettiğini, arzulandığını, anlık olarak değişiklik sergilemeyip süreklilik gösterdiğini söylemiştir. Buradan hareketle, değerlerin toplumsal yaşama etkisinden söz etmek mümkündür.

Değerler, bireyin davranışlarına yön verir. Herhangi bir evrensel değeri doğru tanıyıp, anlayıp, algılayıp, benimseyen bir kişinin, bu değer doğrultusunda davranışlar sergilemesi beklenir. Bu gerçekten yola çıkılarak, değerlerin çocukların zihnindeki algılarının doğru bir biçimde oluşturulmasının son derece önemli olduğu söylenebilir. Örneğin sorumluluğun ne demek olduğunu bilmeyen, sorumlulukla ilgili kavram yanılgısı veya yanlış algısı olan bir çocuktan, sorumluluk gerektiren davranış beklenmemelidir. Bunun yanında, saygı kavramını yanlış bir şekilde algılamış olan çocuğun; nelere nasıl saygı gösterilmesi gerektiği, saygı nın sadece insanlara ya da büyüklere mi gösterildiği, kendisinin sayg1 görmeye layık olup olmadığı gibi durumlarla ilgili doğru davranış sergilemesi oldukça güçtür. Çünkü bu dönemde çocukların algılarında keskinlik ve kesinlikten söz edilemez. Bu nedenle değerler eğitimi konusunda okul öncesi dönem etkileşim ve tecrübe etme dönemi olarak nitelendirilebilir. Ayrıca sevgi olgusu için de benzer şeyleri söylemek mümkündür. Bununla ilgili olarak Benazus (2002), sevgi değerine sahip olan bireyin duygu ve yaşantısında, sadece kendi çevresinin değil tüm dünyanın hatta tüm evrenin var olduğunu belirtmektedir. Bu bağlamda bireylerin, özellikle çocukların; değerlerin ne anlama geldiğini, nasıl yaşanması, nasıl yaşatılması, nasıl yansıtılması gerektiği konusunda doğru algılamalara sahip olmasının son derece önemli olduğu ifade edilebilir.

Myers (1992) toplum olarak istenen ahlaki ve sosyal değerlerin gelecek zamanlarda korunabilmesi amacıyla çocuklara bunların kazandırılması gerektiğini belirtmiştir. Ayrıca Uyanık-Balat ve Balaban-Dağal (2006) değerlere ilişkin 
ilk kazanımların okul öncesi dönemde edinildiğini ve etkilerinin tüm yaşam boyunca devam ettiğini belirtmiştir. Buradan hareketle toplumu etkileyen ve toplu mdan etkilenen değerlerin temellerinin okul öncesi dönemde oluşturulmasın in önemli olduğu söylenebilir. Buraya kadar ifade edildiği gibi; insan davranışlarını küçük yaşlardan itibaren etkileyen en önemli faktörlerden biri olan değerlerin doğru şekilde tanımlanmasına, algılanmasına, anlaşılmasına ve benim senmesine katk1 sağlamak amacıyla, değerler eğitimi sistemli ve planlı olarak gerçekleştirilmelidir. Bu süreçte öncelikle erken çocukluk döneminde bulunan çocukların değer kavramlarını nasıl algıladıkları ve tanımladıklarının tespit edilmesi gerekir.

Erken çocukluk dönemi çocuklarının değerlerle ilgili algı ve tanımlamalarına yönelik çalışmaların diğer yaş gruplarındaki çocuklarla yapılan çalışmalara göre daha az olduğu tespit edilmiştir Özellikle örneklemin çocuklardan oluştuğu araştırmaların sayısı daha azdır. Bu dönem çocuklarını tanıma ve onlarla ilgili araştırma yapmanın çoğu zaman sınırlılıkları vardır. Erken çocukluk dönem inde değerler ve değerlerin algılanması ile ilgili yapılan araştırmalara (Saps ağlam, 2017; Tatlı ve Güngör-Aytar, 2017; Yukay-Yüksel, Canel, Mutlu, Yılmaz ve Çap, 2015; Günindi, 2015) bakıldığında genellikle resim analizi yönteminin kullanıldığı görülmektedir. Ayrıca bu tür çalışmalarda genellikle bir değer seçilerek o değerle ilgili veri toplama yoluna gidilmiştir. Bu çalışmada ise çocukların değerlerle ilgili algılama ve tanımlamaları yüz yüze görüşme yöntemi ile belirlenmeye çalışılmıştır. Bu çalışma, okul öncesi dönemdeki çocukların çeşitli değer kavramlarını nasıl algıladıklarını ve tanımladıklarını araştırmak amacıyla yapılmıştır.

\section{Bilişsel Gelişim ve Değer Kavramlarının Edinimi}

Çocukların gelişimi genetik ve çevresel faktörler ile şekillenir. Birçok çevresel faktör eğitim faaliyetleri çerçevesinde insanı etkilemektedir. Çocuklar erken çocukluk döneminde formal ve informal eğitim almaktadır. Belli bir amaca dayanan ve önceden hazırlanmış bir program çerçevesinde planlı olarak yapılan öğretim faaliyetlerine formal eğitim; yaşam içinde kendiliğinden oluşan ve etkileşim temelli öğrenme yaşantılarına ise informal eğitim denir (Fidan, 2012). Eğitimde ana hedeflerden biri de çocuğun kendisini ve içinde yaşadığı dünyayı anlamlandırması ve uyum sağlamasıdır. Bu hedefi gerçekleştirebilmek için gereken temel araçlardan biri de çevresindeki canlılarla, nesnelerle, olaylarla ve durumlarla ilgili ortak bir düşünüş biçimi olan kavramlardır. Ayrıca toplumda 
üstlenilen roller de değerlerin algılanmasını etkileyebilir. Bununla ilgili olarak Özens el (2007) cinsiyetle ilgili olarak kızların ve erkeklerin toplumsallaşma sürecinde değişik roller üstlenmesinden dolayı ilgi ve değerlerinde farklılıklar olmasının kaçınılmaz olduğunu ifade etmiştir.

İnfor mal eğitim bireyin doğumundan itibaren çevresindekilerle etkileşimi sonuc unda gerçekleşebilir. Bu etkileşim çevredekilerin bilinçli veya bilinçsiz olması, doğru veya yanlış yöntemler kullanması şeklinde olabilir. Çocukların algılama ve tanımlamalarına çevrenin etkisi oldukça yüksektir. Aydın'ın (2003) da ifade ettiği gibi değerler yaşl1-genç, erkek-kadın, eğitimli-eğitimsiz, yoksul-varlıklı gibi farklı demografik özelliklere sahip kişilerce farklı seviyelerde algılanmaktadır. Çocukların verdikleri cevapların kaynağı ile ilgili kesin bilgiye ulaşı lamayacağ için çevreden gelen etkilerin hangi faktörden kaynaklı olduğu tam olarak ortaya konulamayabilir. Bu eğitimde en önemli faktörlerden biri anne baba tutumları ve onların çocuğa zengin uyarıcı ortam sunmasıdır. Çağdaş (2012), hayatın ilk senelerinde ana-baba-çocuk üçgenindeki etkileşim ile edinilen bilgi, beceri ve tavırların yetişkinlik yıllarında önemli rol oynadığını ifade etmektedir. Burada belirtilen, ailenin veya çocukla en fazla etkileşime giren kişilerin geçirdiği kaliteli vakitlerin çocuğun gelişiminde oldukça etkili olmasıdır.

Formal eğitim genel olarak üç yaşından itibaren başlar. Bu yaştan itibaren çocuğa kazandırılmaya çalışılan bilgi, beceri ve tutumları daha sistematik bir şekilde ortaya koymak için gelişim alanları oluşturulmuştur. Bu dönem çocuklarının bilişssel, dil, sosyal-duygusal, motor ve öz bakım alanlarından oluşan beş gelişim/beceri alanı tanımlanmıştır (Milli Eğitim Bakanlı̆̆ı, 2013). Bunlardan biri olan bilişsel gelişim; dikkat, algılama, bellek, anlamlandırma, düşünme, mantık yürütme, yaratıcılık gibi becerileri barındırmaktadır.

Erken çocukluk dönemi çocuklarının bilişsel gelişimi ile ilgili öne çıkan bilim insanlarının Piaget, Vygotsky ve Dewey olduğu söylenebilir. Piaget (1952) çocukların, beyninde kavramlarla ilgili şemalar oluşturduğunu, çevreyle etkileşimle şemalarının değişebildiğini, genişleyebildiğini ve belli deneyimlerden sonra kalıplaştı̆ıııı belirtir. Benzer özelliklere sahip canlılar, nesneler, olaylar ve durumlara verilen ortak isme kavram denildiği düşünüldüğünde, Schwartz ve Bilsky'nin de (1987) belirttiği gibi kavram kategorilerinden biri de değer kavramlarıdır. Değer kavramlarına ilişkin bilinçli olarak oluşturulacak zengin uyarıcı çevre olanakları ile bu kavramlara ait şemalar sağlıklı bir şekil alır. Dolayısıyla değer algılamaları ve tanımlamaları da istendik yönde geliştirilebilir.

Kavram öğrenme; nesneleri, olayları veya insanları benzer özelliklerine göre gruplayabilme ve bu gruba bir bütün olarak tepki geliştirebilme durumu olarak 
tanımlanabilir. Dere ve Ömeroğlu, (2001) çocukların kavram öğrenme aşamalarını tanıma, adlandırma, eşleştirme, sıralama, gruplama ve ayırt etme olarak sıralamaktadır. Bununla birlikte Frostig ve Maslow'a göre (1973) çocuğun evrendeki kavramları olguları anlayabilmesi ve uyarıcıları bazı bilişsel öğelerle eşleştirebilmesi için algılaması gerekir. Bir başka ifade ile kavram edinimi genel olarak algılama ve tanımlama ile başlar. Tüm kavram edinimi basamakları birlikte düşünüldüğünde ilk beceriler doğru bir başlangıç için önemlidir. Çünkü algıl ama ve tanımlama becerileri diğer basamakları derinden etkileyebilecek niteliktedir.

Normal gelişim gösteren bireylerde algılanan kavramlar ile ilgili deneyim arttıkça kavramın algılanması ve tanımlanmasının kolaylaştığı düşünülmektedir. Sözel yönergeler yerine model olunarak, çocuğun algılaması ve tanımlamasının kolay laştııılmasının ve bu yolla algılayıp tanımladığı değerleri davranışa dönüştürmesinin daha olası olduğu düşünülmektedir. Bu davranışlar kısmen kasıt1, çoğu zaman ise ezberlenmiş taklit şeklinde gerçekleşebilir. Sapsağlam'ın da (2016) belirttiği gibi çocuklar bu dönemde gözlem ve taklit yoluyla değerleri öğren ebilir. Tarkoçin, Berktaş ve Uyanık-Balat (2013) tarafından okul öncesi öğretmenleri ile ilgili yapılan çalışmada öğretmenlerin etkinlik sürecinde çocuklarla iletişimlerinde nezaket, sorumluluk, saygı, işbirliği, sevgi/şefkat, sabır, paylaşma, yardımlaşma, adalet, merhamet, hoşgörü ve doğruluk/dürüstlük değerlerine odaklandığı saptanmıştır. Bu değerlerden en çok yer verilen evrensel değerlerin ise nezaket, yardımlaşma, sorumluluk, sevgi ve sabır olduğu ifade edilmiştir. Sapsağlam'ın (2015) çalışmasında ise okul öncesi dönem çocuklarına en uygun değerlerin yardımseverlik, sevgi, saygı, hoşgörü, nezaket, arkadaşlık, işbirliği, sorumluluk, kendini kontrol etme ve dürüstlük olduğu belirtilmektedir.

Okul öncesi dönem çocukları kavramsal algılama öncesinde somut göstergeler üzerinden etkileşime girdikleri için, başka bir ifade ile duyu organları aracılığıyla algılayabildikleri için, değer kavramlarını tanımlarken aynı zamanda soyut nitelik de taşıdıklarından, birçok sebebe bağlı olarak sözlük anlamlarının dışında farklı anlamlar ve farklı tanımlamalarla karşılaşılabilir. Bu durum Piaget' nin şema oluşum süreci ile açıklanabilir. Bu süreçte uyarıcıların zihinde oluşturduğu dengesizlik durumu önceki öğrenmeler ve deneyimlerle dengelenmekte dir (Piaget, 1952). Bireyin etkileşimde olduğu insanların ne söylemek istediğini doğru anlaması iletişimde dikkat edilmesi gereken bir husus olduğu için kişinin kelime dağarcığı ve onu doğru kullanması önemli bir durumdur. Çocukluktan itibaren oluşan algılar ve dağarcık doğru bir şekilde temellendiril- 
melidir. Bu bilgilerden yola çıkılarak bu araştırma; çocukların değerlere yönelik sözel ifadelerini, algılarını ve bunların analiz edilmesini içermesi bakımından önemli görülmektedir. Buradan hareketle araştırmanın konusu olan çocukların sorumluluk, paylaşma, yardımseverlik, arkadaşlık, saygı, dürüstlük ve nezaket değerlerini algılamaları ve tanımlamalarının ortaya konulması, sonraki araştırmalara yol gösterici olma niteliği açısından alana önemli katkılar sağlayacağı ümit edilmektedir.

\section{Yöntem}

Bu çalışmada nitel araştırma yöntemi kullanılmıştır. Yıldırım ve Şimşek (2013) nitel araştırmanın, gözlem, görüşme ve doküman analizi gibi yöntemlerden yararlanılan, algıların ve olayların doğal ortamında ve eksiksiz olarak ortaya çıarılmasında kullanılan bir araştırma türü olduğunu ifade etmiştir. Gay, Mills ve Airasian (2009) nitel araştırmaların temel özelliklerinin; amaçlı bir şekilde seçilen küçük bir çalışma grubu ile bu gruptan toplanan verilerin sayısal yorumlama içermemesi olduğunu vurgulamıştır.

Nitel araştırmalarda olgubilim, durum çalışması, kuram oluşturma, kültür analizi, eylem araştırması gibi farklı araştırma desenleri kullanılabilir. Bu çalışmanın konusuna uygun olduğundan, olgubilim (fenomenoloji) deseni kullanılmıştır. Yıldırım ve Şimşek (2013) olguların, farkında olunan ancak detaylı bilgiye sahip olunmayan olay, durum, deneyim ve algılardan oluşabileceğini belirtmiştir. Ayrıca Patton (2014) fenomenolojinin bireyin fenomene ilişkin algıları, yükledikleri anlam ve hislerini açıklamaya çalıştığını belirtmiştir. Bu çalışmada açıklanmaya çalışılan olgu okul öncesi dönem çocuklarının, belirlenen değerlere ilişkin algılamaları ve tanımlamalarıdır.

\section{Çalışma Grubu}

Araştırmanın çalışma grubunu 2017-2018 eğitim-öğretim y1lında okul öncesi eğitime devam eden altı yaş grubundaki 30 çocuk oluşturmaktadır. Veriler aynı eğitim öğretim yılının güz yarıyılında toplanmıştır. Örneklem belirlenirken amaçlı örnekleme yöntemlerinden tipik durum örneklemesi kullanılmıştır (Patton, 2014). İstanbul ilinin ortalama sosyo-ekonomik niteliğini yansıtacağ sayımı ile bu örnekleme yönteminden faydalanılarak buna uygun bir okul seçilmiştir. Örneklemin tümünün benzer sosyo-ekonomik düzeyde olmasına dikkat edilmiştir. Bununla birlikte katılımcılar daha önce planlı bir değerler eğitimi 
almamış çocuklardan seçilmiştir. Uygulama sırasında bazı çocukların isteksiz davranarak hiçbir cevap vermemesi dikkate alınarak çocuk sayısı 20 olarak revize edilmiştir. İlk aşamada araştırmaya katılan çocukların cinsiyet dağılımının homojen olmasına özen gösterilmiş, çocuklardan bir kısmının araştırmaya dahil edilememesi nedeniyle, daha önce 15-15 olan dağılım erkekler lehine 11-9 olarak gerçekleşmiştir.

Çalışma grubu, MEB tarafından 2012 yılında sınırları 66 ay olarak belirlenen okul öncesi eğitim döneminin son aşamasında olan 60-72 ay çocuklarından oluşturulmuştur. Katılımcıların yaşları tabloda gösterilmekle beraber yaş ortalamas1 66,45 aydır. Katılımcıların orta sosyo-ekonomik düzeye sahip ailelerin çocukları olduğu, bununla birlikte 7 çocuğun okul öncesi eğitimden bir yıldan fazla yararlandığı görülmektedir.

\begin{tabular}{|c|c|c|c|}
\hline Katılımeı Kodu & Çocuğun Yaşı (ay) & Cinsiyet & Okul öncesi eğitimdeki kaçıncı yılı \\
\hline Ç.1. & 64 & $\mathrm{E}$ & 1. y1lı \\
\hline Ç.2. & 63 & $\mathrm{~K}$ & 1. y1l1 \\
\hline Ç.3. & 67 & E & 1. y1li \\
\hline C..4. & 66 & E & 1. y1lı \\
\hline C..5. & 70 & $\mathrm{~K}$ & 2. y1li \\
\hline Ç.6. & 67 & E & 1. y1lı \\
\hline Ç.7. & 60 & $\mathrm{~K}$ & 1. y1lı \\
\hline Ç. 8. & 59 & E & 2. y1li \\
\hline Ç.9. & 69 & $\mathrm{~K}$ & 1. y1l1 \\
\hline Ç.10. & 68 & $\mathrm{~K}$ & 2. y1lı \\
\hline Ç.11. & 68 & E & 1. y1li \\
\hline Ç.12. & 66 & $\mathrm{~K}$ & 1. y1l1 \\
\hline Ç.13. & 69 & $\mathrm{~K}$ & 1. y1lı \\
\hline Ç.14. & 70 & $\mathrm{~K}$ & 3. y1li \\
\hline Ç. 15 . & 71 & E & 3. y1lı \\
\hline C..16. & 70 & E & 2. y1lı \\
\hline Ç.17. & 62 & E & 1. y1lı \\
\hline Ç.18. & 69 & E & 2. y1li \\
\hline Ç.19. & 66 & E & 1. y1lı \\
\hline \multirow[t]{2}{*}{ Ç.20. } & 65 & $\mathrm{~K}$ & 1. y1li \\
\hline & 66,45 & $11 \mathrm{E}, 9 \mathrm{~K}$ & \\
\hline
\end{tabular}




\section{Veri Toplama Araci}

Veri toplama aracı oluşturulurken öncelikle ulusal ve uluslararası alanyazın taranmış, Milli Eğitim Bakanlığı tarafından hazırlanan son dört okul öncesi eğitim programı olan 1994, 2002, 2006 ve 2013 programları incelenmiştir. Ayrıca yapılan literatür taraması (Sapsağlam, 2017; Tatlı ve Güngör-Aytar, 2017; Sapsağlam, 2016; Tozduman-Yaralı, Özkan ve Güngör-Aytar, 2016; Sapsağlam, 2015; Yukay-Yüksel, Canel, Mutlu, Yılmaz ve Çap, 2015; Günindi, 2015; Tarkoçin, Berktaş ve Uyanık-Balat, 2013; Yılmaz, Göçen ve Yılmaz, 2013; Deveci ve Ay, 2009; Kurnaz, Çiftçi ve Karapazar, 2011; Kolukısa, Oruç, Akbaba ve Dündar, 2008; Yavuzer, 2000) sonucunda, bu kaynaklarda da belirtilen çocukların günlük yaşamlarında da sıklıkla karşılaşabilecekleri 12 değer seçilmiştir. $\mathrm{Bu}$ değerler açık uçlu üçer soru şeklinde ifade edilmiştir.

Ardından, nihai çalışma grubuyla aynı niteliklere sahip, aynı okulda bulunan 10 çocukla pilot çalışma gerçekleştirilmiştir. Bu çalışmada çocukların çoğunluğu bazı değerlerle ilgili sorulara cevap verememiştir. Pilot çalışma sonucunda, çocukların gelişim düzeyleri, dikkat süreleri ve alan uzmanlarının görüşleri dikkate alınarak araştııılacak değerlerin belirtilen 7 değer ile sınırlandırılmasına karar verilmiştir. Bunlar sorumluluk, paylaşma, yardımseverlik, saygl, nezaket, arkadaşlık ve dürüstlük değerleridir. Sorular ilgili değerin bilgi-tanımlama, beceri-kullanım ve tutum-yaklaşım boyutları bağlamında tasarlanmıştır. Veri toplama aracındaki değerlerle ilgili, sorumluluk için dört (beceri boyutunda iki adet), diğer değerler için üçer (her bir boyutta birer) olmak üzere toplam 22 soru, alan uzmanlarının görüşü de alınarak hazırlanmıştır. Çıkarılan değer ve sorularla ilgili alan uzmanlarının üçü, çocuğun hayatında fazla yer almadığı ve somutlaştırmada zorlanabileceği yönünde görüş belirtmiştir. Beş alan uzmanından ikisi okul öncesi eğitimi (biri profesör, diğeri doçent), biri çocuk gelişimi (doktor öğretim üyesi), biri ölçme değerlendirme (doçent), biri din eğitimi (doktor öğretim üyesi) alanlarında görev yapmaktadır.

Çocukların değer kavramları ile ilgili algılamalarını ve tanımlamalarını yordayabilmek için yedi değerle ilgili açık uçlu soruları içeren veri toplama formu oluşturulmuştur. Fakat çocuklara cevaplarını sözel ifadeler veya jest ve mimik gibi beden dili unsurlarıyla da verebilecekleri söylenmiştir. Formda (EK-1) her bir değer ile ilgili algı ve kavrama düzeyinde sorular bulunmaktadır. Çocuklara araştırmacılar tarafından seçilen 7 değer ile ilgili 22 sorudan oluşan açık uçlu form yüz yüze görüşme yöntemiyle uygulanmıştır. 
Veri toplama formunda bulunan sorular araştırmacılar tarafindan anasınıfı çocukları ile tanışıldıktan ve yaklaşık bir saat beraber vakit geçirildikten sonra yüz yüze görüşme yöntemiyle uygulanmıştır. Özellikle okul öncesi dönem çocuklarıyla çalışılan araştırmalarda görüşme tekniği kullanılırken dikkat edilmesi gerekenler, çocukların sosyal ve duygusal özelliklerine bağlı hassasiyetleri öğretmenlerinin görüşü doğrultusunda göz önünde bulundurulmuştur. Bu doğrultuda çocukları endişeye sevk edecek ya da cevaplarını etkileyecek davranışlardan kaçınılmıştır.

\section{Geçerlik ve Güvenirlik}

Yıldırım ve Şimşek (2013), Lincoln ve Guba'nın nitel araştırmalarda niteliği arttırmak için belirli stratejiler oluşturduğunu; bu stratejilerde nicel araştırmalardaki geçerlilik ve güvenirlik kavramlarına alternatif olarak iç geçerlilik yerine inandırıcılık, dış geçerlilik yerine aktarılabilirlik, iç güvenirlik yerine tutarlık ve dış güvenirlik yerine teyit edilebilirlik gibi nitel araştırmanın doğasına uygun yeni kavramlar önerdiğini aktarmaktadır.

$\mathrm{Bu}$ araştırmada inandırıcılık kriterini sağlamak için veri toplama formunda bulunan sorular, araştırmada elde edilen veriler ve bu verilerle ilgili yapılan yorumlara yönelik olarak okul öncesi eğitim ve ölçme değerlendirme uzmanlarından görüş alınmıştır. Ek olarak çalışmanın inandırıcılığı, araştırmaya katılan çocukların öğretmenlerine elde edilen veriler gösterilerek alınan onay ile desteklenmiştir. Dış geçerliği sağlamak için çocukların araştırmaya ilişkin ifadeleri doğrudan aktarılarak verilmiştir. Aktarılabilirlik özelliğine yönelik olarak, veriler, sonuçlar ve yorumlar erken çocukluk eğitimi ve ölçme değerlendirme alan uzmanlarının değerlendirmesine sunulmuştur. Teyit edilebilirlik için literatür taraması sonucunda yarı yapılandırılmış görüşme formu hazırlanmıştır.

Nitel araştırma yönteminde geçerliğin oluşturulmasını sağlayan durum, araştırma alanına yatkınlık, yüz yüze görüşme yöntemi aracılığıyla detaylı bilgi toplama, gözlem aracılığıla bilgi toplama, toplanan bilgilerin doğrulanması için alana tekrar giderek ek bilgi toplama imkanının var olmasıdır (Yıldırım ve Şimşek, 2013). Bu çalışma kapsamında, çalışma grubundaki çocuklardan, görüşme yöntemi kullanılarak doğrudan bilgi toplanmış ve verilerin analizi gerçekleştirilmiş̧ir. Görüşme yapılan çocukların değer kavramlarını algılama ve tanımlamaları ile ilgili ifadeler, kod isim verilerek alıntılanmıştır. Bu işlemler Patton'un (2014) da belirttiği gibi iki veya daha fazla uzmanın elde edilen nitel veriyi analiz etmesi şeklinde yapılan ve üçgenleme olarak ifade edilen teknikle 
gerçekleştirilmiştir. Patton (2014) birden fazla bakış açısının kullanılmasının araştırmanın niteliğini arttıracağını vurgulamaktadır. Bu bağlamda bu araştırmada üçgenleme çeşitlerinden araştırmacı çeşitlemesi kullanılmıştır.

\section{Verilerin Analizi}

Elde edilen verilerin analiz edilmesinde içerik analizi tekniğinden yararlanılmıştır. Görüşme sonunda çocukların verdikleri cevaplar içerik analiziyle değerlendirilerek kodlanmış ve temalar oluşturulmuştur. Yıldırım ve Şimşek’e göre (2013) içerik analiziyle temalar ve ilişkiler belirlenmeye çalış1lır. İçerik analizinin temel yapısında verilerdeki benzer ögeleri, oluşturulan kavram ve temalarla çerçeveleyerek yararlanıcıların anlayabileceği şekilde organize edip yorumlama bulunmaktadır. Bu işlemler; verilerin kodlanması, temaların oluşturulması, kodların ve temaların düzenlenmesi ve bulguları tanımlayıp yorumlama olmak üzere dört aşamadan oluşur. İçerik analizi sürecinde her değer ile ilgili çocuklardan alınan cevaplara göre kodlar ve temalar oluşturulmuş, kategorize edilen temalar frekans verileriyle beraber sunulmuştur.

\section{Bulgular}

Bu bölümde, okul öncesi dönem çocuklarının değer kavramlarına ilişkin algılamalarını ve tanımlamalarını belirlemek için sorulan sorulara, cevaplardan oluşturulan kodlara, kodlardan ulaşılan temalara ve doğrudan alıntılara yer verilmiştir. Çocuklardan alınan cevaplar, içerik analizi tekniği kullanılarak çözümlenmiştir. Her soru için alınan cevaplardan birbirine yakın ifadeler maddeler halinde yazılarak kodlanmıştır. Daha sonra bu kodlardan temalara ulaşılmış, kategorize edilerek tablo haline getirilmiştir. Tablolardaki her kod için çocukların verdiği cevapların bulunma sayısı frekans sütununa yazılmıştır.

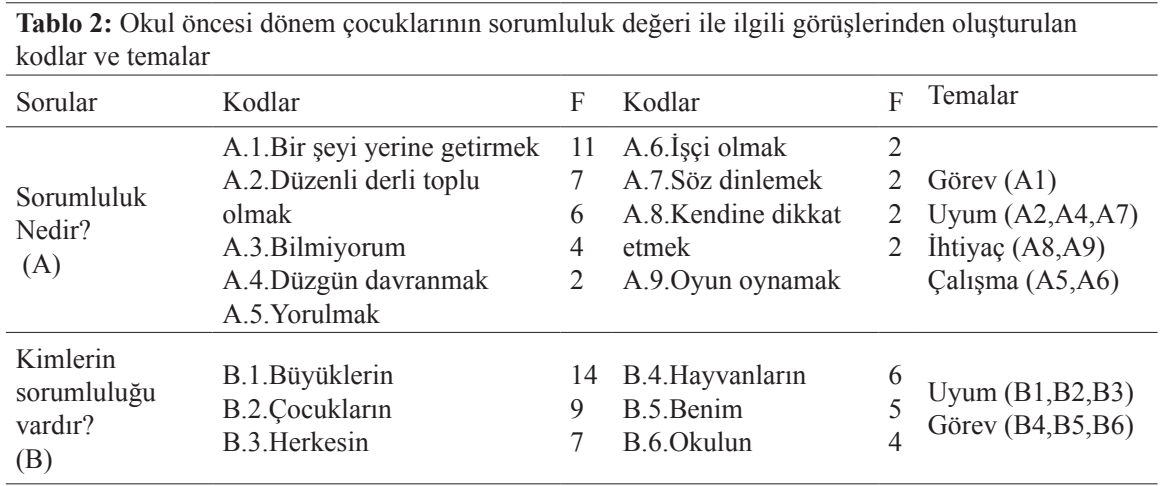




\begin{tabular}{|c|c|c|c|c|c|}
\hline $\begin{array}{l}\text { Senin } \\
\text { sorumlulukların } \\
\text { nelerdir? } \\
\text { (C) }\end{array}$ & $\begin{array}{l}\text { C.1.Düzenli derli toplu } \\
\text { olmak } \\
\text { C.2.Anneme yardım etmek } \\
\text { C.3.Düzgün davranmak } \\
\text { C.4.Ödev yapmak } \\
\text { C.5.Oyun oynamak } \\
\text { C.6.Yemek yemek }\end{array}$ & $\begin{array}{l}11 \\
9 \\
6 \\
6 \\
5 \\
3\end{array}$ & $\begin{array}{l}\text { C.7.Anne babamı } \\
\text { mutlu etmek } \\
\text { C.8.Okula gelmek } \\
\text { C.9.Kendi yatağında } \\
\text { yatmak } \\
\text { C.10.Hayal kurmak } \\
\text { C.11.Yatmak }\end{array}$ & $\begin{array}{l}3 \\
2 \\
2 \\
2 \\
1\end{array}$ & $\begin{array}{l}\text { Uyum } \\
\text { (C1,C2,C3,C9) } \\
\text { Görev (C4,C8) } \\
\text { İhtiyaç } \\
\text { (C5,C6,C10,C11) } \\
\text { İyilik (C7) }\end{array}$ \\
\hline $\begin{array}{l}\text { Sorumluluklar } \\
\text { yerine } \\
\text { getirilmezse ne } \\
\text { olur? } \\
\text { (D) }\end{array}$ & $\begin{array}{l}\text { D.1.Bize kızarlar } \\
\text { D.2.Her yer dağını olur } \\
\text { D.3.Annem yorulur üzülür } \\
\text { D.4.Etraf kirlenir }\end{array}$ & $\begin{array}{l}13 \\
6 \\
6 \\
5\end{array}$ & $\begin{array}{l}\text { D.5.İşlerimiz yarım } \\
\text { kalır } \\
\text { D.6.Bir yerimiz } \\
\text { yaralanır } \\
\text { D.7.Dünya saçma } \\
\text { sapan olur } \\
\text { D.8.İsteklerimiz } \\
\text { yerine getirilmez }\end{array}$ & $\begin{array}{l}5 \\
2 \\
1 \\
1\end{array}$ & $\begin{array}{l}\text { Suç-Ceza (D1) } \\
\text { Uyum } \\
\text { (D2,D4,D5,D7) } \\
\text { İyilik (D3) } \\
\text { Temkin (D6) } \\
\text { Ç1kar (D8) }\end{array}$ \\
\hline
\end{tabular}

Tablo 2'de görüldüğü gibi çocukların sorumluluk değeri ile ilgili sorulara verdiği cevaplara ilişkin kavramlar kodlanmıştır. "Sorumluluk nedir?” Sorusuna çocukların verdikleri cevaplardan yola çıkılarak oluşturulan kodlardan görev, uyum, ihtiyaç ve çalışma temaları oluşturulmuştur. Çocukların yarısından fazlaS1 görev temasının altındaki kod olan "bir şeyi yerine getirmek" doğrultusunda cevaplar vermiştir. Çocukların az bir kısmı ise ihtiyaç teması altındaki kod olan "oyun oynamak" anlamına gelen ifadeler dile getirmiştir. Verilen cevaplardan bazıları doğrudan şu şekildedir:

Ç.5: "Birisinin verdiği işi başkasına vermeden kendin yapmak..." (A.1., A.7.)

Ç.6: "Etrafi toplamak..." (A.2.)

Ç.15: "Babam bize yaptırıyor, o işte." (A.7.)

Ç.10: "Oyuncakla oynamak..." (A.9.)

Sorumluluk değerine ilişkin "Kimlerin sorumlulukları vardır?" Sorusuna çocukların verdikleri cevaplardan yola çıkılarak oluşturulan kodlardan uyum ve görev temaları oluşturulmuştur. Çocukların büyük bir kısmı uyum teması altındaki kodlar olan "büyüklerin”, “çocukların”, "herkesin” anlamına gelen cevaplar vermiştir. Çocukların bir kısmı ise görev teması altındaki kodlar olan "okulun" ve "kendinin" bağlamında ifadeler kullanmıştır. Verilen cevaplardan bazıları doğrudan şu şekildedir:

Ç.16: “Adamların, köpeklerin...” (B.1., B.4.)

Ç.14: "Annelerin, babaların, abilerin, ablaların, çocukların..." (B.1., B.2.)

Ç.13: "Okulun, benim..." (B.6., B.5.)

Sorumluluk değerine ilişkin "Senin sorumlulukların nelerdir?" Sorusuna çocukların verdikleri cevaplardan yola çıkılarak oluşturulan kodlardan uyum, görev, ihtiyaç ve iyilik temaları oluşturulmuştur. Çocukların yarısından fazlası uyum temasının altındaki kod olan "düzenli derli toplu olmak", yarıya yakın 
kısmı ise yine uyum temasının altındaki kod olan "anneme yardım etmek" anlamına gelebilecek cevaplar vermiştir. Az sayıda çocuk ise iyilik teması altındaki kod olan "anne-babayı mutlu etmek" anlamına gelen ifadeler kullanmıştır. Verilen cevaplardan bazıları doğrudan şu şekildedir:

Ç.10: "Evde kendim yatmak, annemle babamla yatarsam ayıp olur." (C.9.)

Ç.7: "Odamı toplamak, güzel davranmak..." (C.1., C.3.)

Ç.6: "Her tarafı temiz tutmam, oyuncaklarımı toplamam lazım." (C.1.)

Ç.12: "Ödevimi yaparım, kardeşimle oynarım, Annem sevinir bu sefer. Bir de şey, annem hasta olunca yardım edersem de sevinir.” (C.2., C.4., C.5., C.7.)

Sorumluluk değerine ilişkin "Sorumluluklar yerine getirilmezse ne olur?" Sorusuna çocukların verdikleri cevaplardan yola çıkılarak oluşturulan kodlardan suç-ceza, uyum, iyilik, temkin ve çıar temaları oluşturulmuştur. Çocukların yarısından fazla bir kısmı suç-ceza teması altındaki kod olan "bize kızarlar" anlamına gelen cevaplar vermiştir. Çocuklardan 1 tanesi ise çıkar teması altındaki kod olan "isteklerimiz yerine getirilmez" anlamına gelen ifadeler kullanmıştır. Verilen cevaplardan bazıları doğrudan şu şekildedir:

Ç.4: "Bizim isteklerimizi yapmazlar." (D.8.)

Ç.7: "Ödevimi yapmayınca öğretmen bana kızar." (D.1.)

Ç.3: "Anne çok yorulur, her şeyi o yapar." (D.3.)

Ç.1: "Kızar patronlar." (D.8.)

Tablo 3: Okul öncesi dönem çocuklarının paylaşma değeri ile ilgili görüşlerinden oluşturulan kodlar ve temalar

\begin{tabular}{|c|c|c|c|c|c|}
\hline Sorular & Kodlar & F & Kodlar & $\mathrm{F}$ & Temalar \\
\hline $\begin{array}{l}\text { Paylaşmak } \\
\text { ne demektir? } \\
\text { (E) }\end{array}$ & $\begin{array}{l}\text { E.1.Başkasına vermek } \\
\text { E.2.Güzel bir şey } \\
\text { E.3.Oyuncakları başkasıy- } \\
\text { la oynamak } \\
\text { E.4.Eğlenmektir }\end{array}$ & $\begin{array}{l}12 \\
8 \\
7 \\
4\end{array}$ & $\begin{array}{l}\text { E.5.İstediğini yapabil- } \\
\text { mektir } \\
\text { E.6.Kardeş olmak } \\
\text { E.7.İkiye bölmek } \\
\text { E.8.Bilmiyorum }\end{array}$ & $\begin{array}{l}2 \\
2 \\
1\end{array}$ & $\begin{array}{l}\text { İyilik } \\
\text { (E1,E2,E3,E6,E7) } \\
\text { İhtiyaç (E4) } \\
\text { Özgürlük (E5) }\end{array}$ \\
\hline $\begin{array}{l}\text { Niçin payla- } \\
\text { şılmalıdır? } \\
\text { (F) }\end{array}$ & $\begin{array}{l}\text { F.1.Benimle arkadaşlık } \\
\text { yapsınlar diye } \\
\text { F.2.Arkadaşım üzülmesin } \\
\text { diye } \\
\text { F.3.Canım istediği için } \\
\text { F.4.Allah istediği için }\end{array}$ & $\begin{array}{l}13 \\
8 \\
3 \\
2\end{array}$ & $\begin{array}{l}\text { F.5.Sana iyilik yapanlara } \\
\text { yardım için } \\
\text { F.6.Güzel bir şey olduğu } \\
\text { için } \\
\text { F.7.Oyuncak günü olduğu } \\
\text { için } \\
\text { F.8.Annesine şikayet } \\
\text { etmesin diye }\end{array}$ & $\begin{array}{l}2 \\
2 \\
1 \\
1\end{array}$ & $\begin{array}{l}\text { Ç1kar (F1,F5) } \\
\text { Suç-Ceza (F8) } \\
\text { Özgürlük (F3) } \\
\text { Görev (F4) } \\
\text { İyilik (F2,F6) } \\
\text { Uyum (F7) }\end{array}$ \\
\hline $\begin{array}{l}\text { Neler payla- } \\
\text { ş1labilir? } \\
\text { (G) }\end{array}$ & $\begin{array}{l}\text { G.1.Oyuncaklar } \\
\text { G.2.Bazı eşyalar } \\
\text { G.3.Kitaplar } \\
\text { G.4.Yiyecek-içecek }\end{array}$ & $\begin{array}{l}16 \\
10 \\
8 \\
6\end{array}$ & $\begin{array}{l}\text { G.5.Her şey } \\
\text { G.6.Birden fazla olanlar } \\
\text { G.7.Lazım olmayanlar } \\
\text { G.8.Giysi }\end{array}$ & $\begin{array}{l}2 \\
1 \\
1\end{array}$ & $\begin{array}{l}\text { İyilik (G1,G3,G4,- } \\
\text { G5,G8) } \\
\text { Ç1kar (G2,G6,G7) }\end{array}$ \\
\hline
\end{tabular}

Tablo 3 'te görüldüğü gibi çocukların paylaşma değeri ile ilgili sorulara verdiği cevaplara ilişkin kavramlar kategorize edilmiştir. "Paylaşmak ne demektir?" 
Sorusuna çocukların verdikleri cevaplardan yola çıkılarak oluşturulan kodlardan iyilik, ihtiyaç ve özgürlük temaları oluşturulmuştur. Çocukların büyük bir kısmı iyilik teması altındaki kodlar olan "başkasına vermek", "güzel bir şey" ve "oyuncaklarını başkasıyla oynamak" anlamına gelen cevaplar vermiştir. Çocuklardan bir kısmı ise ihtiyaç teması altındaki kod olan "eğlenmek" anlamına gelen ifadeler kullanmıştır. Verilen cevaplardan bazıları doğrudan şu şekildedir:

Ç.4: "Vermek..." (E.1.)

Ç.5: "Mesela kalemi yoksa ona veririm." (E.1.)

Ç.10: "Oyuncakları birbirimize vermek..." (E.1., E.3.)

Ç.8: "Bir mama ikiye bölündü, iki bebek de yedi." (E.7.)

Paylaşma değerine ilişkin "Niçin paylaşılmalıdır?" Sorusuna çocukların verdikleri cevaplardan yola çıkılarak oluşturulan kodlardan çıkar, suç-ceza, özgürlük, görev, iyilik ve uyum temaları oluşturulmuştur. 13 çocuk çıkar teması altındaki kod olan "benimle arkadaşlık yapsınlar diye" anlamına gelen cevaplar vermiştir. Çocuklardan 1 tanesi ise suç-ceza teması altındaki kod olan "annesine şikayet etmesin diye" anlamına gelen ifadeler kullanmıştır. Verilen cevaplardan bazıları doğrudan şu şekildedir:

Ç.11: “Arkadaş olmak için..." (F.1.)

Ç.13: "Herkes mutlu olsun diye. Arkadaşlığımız devam eder." (F.1., F.2.)

Ç.17: "Oynattıryyorlar bizi o zaman. Yoksa oynatmazlar." (F.1.)

Ç.18: "O sana iyilik yapmıştır, sen de söz vermişsindir." (F.5.)

Paylaşma değerine ilişkin "Neler paylaşılabilir?" Sorusuna çocukların verdikleri cevaplardan yola çıkılarak oluşturulan kodlardan iyilik ve çıar temaları oluşturulmuştur. Çocukların büyük bir kısmı iyilik teması altındaki kodlar olan "oyuncaklar", "kitaplar", "yiyecek-içecek" ve "her şey” anlamına gelen cevaplar vermiştir. Çocukların az bir kısmı ise çıkar teması altındaki kodlar olan "lazım olmayanlar" ve "birden fazla olanlar" anlamına gelen ifadeler kullanmıştır. Verilen cevaplardan bazıları doğrudan şu şekildedir:

Ç.13: "Oyuncak, yemek, içecek, her şeyi paylaşmak gerek. Dünya sevinsin." (G.1., G.4., G.5.)

Ç.11: "Oyuncaklar, eşyalar paylaşırım. Suyumu paylaşmam çünkü ağızdan bulaşır." (G.1., G.2.)

Ç.9: "Sağl1klı yemekler, yumurta, sebze, kebap, süt, peynir..." (G.4.)

Ç.8: "Her şeyi paylaşabiliriz, iki tane ve çok olanları." (G.5., G.6.) 


\begin{tabular}{|c|c|c|c|c|c|}
\hline Sorular & Kodlar & $\mathrm{F}$ & Kodlar & $\mathrm{F}$ & Temalar \\
\hline $\begin{array}{l}\text { Yardım etmek } \\
\text { ne demektir? } \\
\text { (H) }\end{array}$ & $\begin{array}{l}\text { H.1.Beraber yapmak, birlik } \\
\text { olmak } \\
\text { H.2.Düşeni kaldırmak } \\
\text { H.3.Güzel bir şey } \\
\text { H.4.Anneye yemekte yardım } \\
\text { H.5.Yapamayan birinin yerine } \\
\text { yapmak }\end{array}$ & $\begin{array}{l}9 \\
8 \\
5 \\
5 \\
2\end{array}$ & $\begin{array}{l}\text { H.6.Herkese yardım } \\
\text { etmek } \\
\text { H.7.İştir } \\
\text { H.8.Destek olmak } \\
\text { H.9.Birini hastaneye } \\
\text { götürmek }\end{array}$ & $\begin{array}{l}2 \\
2 \\
2 \\
1\end{array}$ & $\begin{array}{l}\text { Uyum } \\
\text { (H1,H4) } \\
\text { İyilik } \\
\text { (H2,H3,H5, } \\
\text { H6,H8,H9) } \\
\text { Görev (H7) }\end{array}$ \\
\hline $\begin{array}{l}\text { Daha önce } \\
\text { yardım ettin } \\
\text { mi, nasıl? } \\
\text { (I) }\end{array}$ & $\begin{array}{l}\text { I.1.Aileme evde } \\
\text { I.2.Arkadaşım düştüğünde } \\
\text { I.3.Arkadaşıma toplanmasında }\end{array}$ & $\begin{array}{l}11 \\
6 \\
6\end{array}$ & $\begin{array}{l}\text { I.4.Öğretmenime } \\
\text { sinıfta } \\
\text { I.5.Bitkilere } \\
\text { I.6.Hayvanlara }\end{array}$ & $\begin{array}{l}4 \\
4 \\
3\end{array}$ & $\begin{array}{l}\text { İyilik } \\
\text { (I2,I3,I5,I6) } \\
\text { Uyum }(\mathrm{I} 1, \mathrm{I} 4)\end{array}$ \\
\hline $\begin{array}{l}\text { Daha önce } \\
\text { yardım aldın } \\
\text { mı, nasıl? } \\
\text { (J) }\end{array}$ & $\begin{array}{l}\text { J.1.Hatırlamıyorum } \\
\text { J.2.Arkadaşımdan, oyun oynar- } \\
\text { ken } \\
\text { J.3.Düştüğümde arkadaşımdan }\end{array}$ & $\begin{array}{l}9 \\
7 \\
5\end{array}$ & $\begin{array}{l}\text { J.4.Oyuncak toplarken } \\
\text { ailemden } \\
\text { J.5.Almadım }\end{array}$ & $\begin{array}{l}5 \\
4\end{array}$ & $\begin{array}{l}\text { Çıkar (J1,J5) } \\
\text { İyilik (J3,J4) } \\
\text { Uyum (J2) }\end{array}$ \\
\hline
\end{tabular}

Tablo 4'te görüldüğü gibi çocukların yardımlaşma değeri ile ilgili sorulara verdiği cevaplara ilişkin kavramlar kategorize edilmiştir. "Yardım etmek ne demektir?” Sorusuna çocukların verdikleri cevaplardan yola çıkılarak oluşturulan kodlardan uyum, iyilik ve görev temaları oluşturulmuştur. Çocukların yarıya yakını uyum teması altındaki kod olan "beraber yapmak, birlik olmaz" anlamına gelen cevaplar vermiştir. Diğer yarısı ise iyilik teması altındaki kodlar olan “düşeni kaldırmak”, "güzel bir şey” ve "anneye yemekte yardım” anlamına gelen ifadeler kullanmıştır. Verilen cevaplardan bazıları doğrudan şu şekildedir:

Ç.16: "Evin tahtasını çakmaya çalışan bir amcaya bir abi yardım ediyor." (H.5., H.8.)

Ç.13: "Düşen birine el uzatıp kaldırmak... O zaman mutlu olur.” (H.2.)

Ç.8: "Biri ipi tutamıyorsa ona ipi tutmaktır." (H.5.)

Ç.18: "Ayağı sakatlanan arkadaşım beni hastaneye götür derse götürürüm.” (H.9.)

Yardımseverlik değerine ilişkin "Daha önce yardım ettin mi, nasıl?” Sorusuna çocukların verdikleri cevaplardan yola çıkılarak oluşturulan kodlardan iyilik ve uyum temaları oluşturulmuştur. Çocukların çoğunluğu uyum teması altındaki kodlar olan "aileme evde" ve "öğretmenime okulda" anlamına gelen cevaplar vermiştir. Çocukların bir kısmı ise iyilik teması altındaki kodlar olan "arkadaşım düştüğünde", "arkadaşıma toplanmasında", "bitkilere" ve "hayvanlara" anlamına gelen ifadeler kullanmıştır. Verilen cevaplardan bazıları doğrudan şu şekildedir:

Ç.4: "Annem kurabiye yaparken yardım ettim." (I.1.)

Ç.6: "Arkadaşım düştügüünde ona yardım ettim." (I.2.)

Ç.7: “Arkadaşım okulda sınıfı topluyordu, ben de ona yardım ettim.” (I.3.) 
Yardımseverlik değerine ilişkin "Daha önce yardım aldın mı, nasıl?" Sorusuna çocukların verdikleri cevaplardan yola çıkılarak oluşturulan kodlardan çıkar, iyilik ve uyum temaları oluşturulmuştur. Çocukların yarısından fazlası çıkar teması altındaki kodlar olan "hatırlamıyorum" ve" almadım" anlamına gelen cevaplar vermiştir. Çocukların bir kısmı uyum teması altındaki kod olan "arkadaşımdan, oyun oynarken"; diğer kısmı ise iyilik teması altındaki kodlar olan "düştüğümde arkadaşımdan" ve "oyuncak toplarken ailemden" anlamına gelen ifadeler kullanmıştır. Verilen cevaplardan bazıları doğrudan şu şekildedir:

Ç.2: "Ben düşmüştüm, iki arkadaşım bana yardım etti." (J.3.)

Ç.1: "Yardım etmedi kimse." (J.5.)

Ç.17: “................. etti, oyuncakları toplarken.” (J.2.)

Ç.9: "Etmediler galiba, çünkü hatırlamıyorum." (J.5.)

Tablo 5: Okul öncesi dönem çocuklarının saygı değeri ile ilgili görüşlerinden oluşturulan kodlar ve temalar

\begin{tabular}{|c|c|c|c|c|c|}
\hline Sorular & Kodlar & $\mathrm{F}$ & Kodlar & $\mathrm{F}$ & Temalar \\
\hline $\begin{array}{l}\text { Saygı ne } \\
\text { demektir? } \\
\text { (K) }\end{array}$ & $\begin{array}{l}\text { K.1.Saygilı davranmak } \\
\text { K.2.Güzel bir şey } \\
\text { K.3.Büyüklere güzel } \\
\text { davranmak } \\
\text { K.4.Uslu davranmak } \\
\text { K.5.Kötü konuşmamak }\end{array}$ & $\begin{array}{l}12 \\
7 \\
4 \\
3 \\
3\end{array}$ & $\begin{array}{l}\text { K.6.Kızmamak } \\
\text { K.7.Engellilere yardım } \\
\text { etmek } \\
\text { K.8.Güzel konuşmak } \\
\text { K.9.Gösterilen bir şey } \\
\text { K.10.Sözünü tutmak }\end{array}$ & $\begin{array}{l}2 \\
1 \\
1 \\
1 \\
1\end{array}$ & $\begin{array}{l}\text { Uyum } \\
\text { (K1,K4,K5,K8,K10) } \\
\text { İyilik (K2,K7) } \\
\text { Tolerans (K6) } \\
\text { Hürmet }(\mathrm{K} 3, \mathrm{~K} 9)\end{array}$ \\
\hline $\begin{array}{l}\text { Nelere saygı } \\
\text { duyulmalı- } \\
\text { dır? } \\
\text { (L) }\end{array}$ & $\begin{array}{l}\text { L.1.Büyüklere } \\
\text { L.2.Arkadaşlarıma } \\
\text { L.3.Hayvanlara } \\
\text { L.4.Doğaya } \\
\text { L.5.Oyuncaklara } \\
\text { L.6.Engellilere } \\
\end{array}$ & $\begin{array}{l}14 \\
9 \\
8 \\
5 \\
5 \\
3 \\
\end{array}$ & $\begin{array}{l}\text { L.7.İşlerimize } \\
\text { L.8.Küçüklere } \\
\text { L.9.Eşyalara } \\
\text { L.10.Allah'a } \\
\text { L.11.Atatürk'e } \\
\text { L.12.Kötü konuşmayanlara }\end{array}$ & $\begin{array}{l}2 \\
2 \\
2 \\
1 \\
1 \\
1\end{array}$ & $\begin{array}{l}\text { Hürmet (L1) } \\
\text { Görev } \\
\text { (L5,L7,L9,L10,L11) } \\
\text { Uyum (L2,L12) } \\
\text { İyilik (L3,L4,L6) } \\
\text { Şefkat (L8) }\end{array}$ \\
\hline $\begin{array}{l}\text { Saygısızca } \\
\text { davranıldı- } \\
\text { ğında neler } \\
\text { olur? } \\
\text { (M) }\end{array}$ & $\begin{array}{l}\text { M.1.Bize kızarlar } \\
\text { M.2.Bilmiyorum } \\
\text { M.3.Bizi sevmezler } \\
\text { M.4.Insanlar üzülür } \\
\text { M.5.Bize küserler }\end{array}$ & $\begin{array}{l}11 \\
5 \\
5 \\
4 \\
3\end{array}$ & $\begin{array}{l}\text { M.6.Zarar verebiliriz } \\
\text { M.7.Bize güvenmezler } \\
\text { M.8.Bizle dalga geçerler } \\
\text { M.9.Doğa bize hiçbir şey } \\
\text { vermez } \\
\text { M.10.Öğretmen küçük } \\
\text { gruba alır }\end{array}$ & $\begin{array}{l}2 \\
2 \\
2 \\
1 \\
1\end{array}$ & $\begin{array}{l}\text { Suç-Ceza } \\
\text { (M1,M8,M10) } \\
\text { Çıkar } \\
\text { (M3,M5,M7,M9) } \\
\text { İyilik (M4,M6) }\end{array}$ \\
\hline
\end{tabular}

Tablo 5'te görüldügü gibi çocukların saygı değeri ile ilgili sorulara verdiği cevaplara ilişkin kavramlar kategorize edilmiştir. "Saygı ne demektir?" Sorusuna çocukların verdikleri cevaplardan yola çıkılarak oluşturulan kodlardan uyum, iyilik, tolerans ve hürmet temaları oluşturulmuştur. Çocukların çoğunluğu uyum teması altındaki kodlar olan "sayg11 davranmak", "uslu davranmak", "kötü konuşmamak", "güzel konuşmak" ve "sözünü tutmak" anlamına gelen cevaplar vermiştir. Çocukların bir kısmı ise hürmet teması altındaki kodlar olan "büyüklere güzel davranmak" ve "güzel bir şey" anlamına gelen ifadeler kullanmıştır. Verilen cevaplardan bazıları doğrudan şu şekildedir: 
Ç.9: "Dedelerimize, annelerimize saygıll davranırız." (K.1.)

Ç.13: "Çok güzel bir şeydir." (K.2.)

Ç.19: "Güzel bir şeydir, saygı1lı davranmaktır." (K.1., K.2.)

Ç.4: "Güzel, iyi davranmak, güzel sözler söylemek..." (K.1., K.5., K.8.)

Saygı değerine ilişkin "Nelere saygı duyulmalıdır?" Sorusuna çocukların verdikleri cevaplardan yola çıkılarak oluşturulan kodlardan hürmet, görev, uyum, iyilik ve şefkat temaları oluşturulmuştur. Çocukların büyük bir kısmı hürmet teması altındaki kod olan "büyüklere" anlamına gelen cevaplar vermiştir. Çocukların diğer bir büyük kısmı ise görev teması altındaki kodlar olan "oyuncaklara”, "işlerimize", "eşyalara”, "Allah'a" ve "Atatürk'e” anlamına gelen ifadeler kullanmıştır. Verilen cevaplardan bazıları doğrudan şu şekildedir:

Ç.6: "Kedilere, hayvanlara, tavşanlara..." (L.3.)

Ç.2: "Yaşlılara, büyüklere, çiçeklere, hayvanlara..." (L.1., L.3., L.4.)

Ç.1: "Şekerlere..." (L.9.)

Ç.17: "Oyuncaklara, yataklara, Atatürk'e..." (L.5., L.9., L.11.)

Saygı değerine ilişkin "Saygısızca davranıldığında neler olur?” Sorusuna çocukların verdikleri cevaplardan yola çıkılarak oluşturulan kodlardan suç-ceza, çıkar ve iyilik temaları oluşturulmuştur. Çocukların yarısından fazlası suç-ceza teması altındaki kodlar olan "bize kızarlar", "bizimle dalga geçerler" ve "öğretmen küçük gruba alır" anlamına gelen cevaplar vermiştir. Çocukların az bir kısmı ise iyilik teması altındaki kodlar olan "insanlar üzülür" ve "zarar verebiliriz" anlamına gelen ifadeler kullanmıştır. Verilen cevaplardan bazıları doğrudan şu şekildedir:

Ç.16: "Kaka falan diyenleri Allah uçurumdan düşürür, yangına götürür yakar." (M.1.)

Ç.10. "Kurallara uymamış oluruz." (M.3., M.6., M.7.)

Ç.12: "Bizi hiç kimse sevmez ve oynamaz. Bizimle dalga geçer." (M.3., M.8.)

Ç.9: "Kimse bana güvenmez." (M.7.)

Tablo 6: Okul öncesi dönem çocuklarının nezaket değeri ile ilgili görüşlerinden oluşturulan kodlar ve temalar

\begin{tabular}{llllll}
\hline Sorular & \multicolumn{1}{c}{ Kodlar } & F & \multicolumn{1}{c}{ Kodlar } & F & Temalar \\
\hline & N.1.Bilmiyorum & & & & \\
Nazik olmak ne & N.2.Güzel davranmak & 9 & N.6.Kaba olmamak & 2 & İyilik (N2,N8) \\
demektir? & N.3.Kibar olmak & 6 & N.7.Dövmemek & 2 & Uyum \\
(N) & N.4.Uslu durmak & 4 & N.8.Paylaşmak & 1 & (N3,N4,N5, \\
& N.5.Güzel ve yavaş & 3 & N.9.Aşılk olmak & 1 & N6,N7,N9) \\
& konuşmak & 3 & & & \\
\hline
\end{tabular}




\begin{tabular}{|c|c|c|c|c|c|}
\hline \multirow{7}{*}{$\begin{array}{l}\text { Niçin nazik } \\
\text { davranılmalıdır? } \\
\text { (O) }\end{array}$} & & & O.6.Gülümsemek için & & Suç-Ceza \\
\hline & O.1.Bilmiyorum & 8 & O.7.Arkadaş kalalım & 2 & $(02,09)$ \\
\hline & O.2.Bize kızmasınlar diye & 6 & diye & 2 & Çikar \\
\hline & O.3.Paylaşmak için & 3 & O.8.Güzel davranmayı & 1 & $(03,04,05)$ \\
\hline & O.4.Saygı duymaları için & 3 & öğrenmek için & 1 & (06) \\
\hline & O.5.Bize küsmesinler diye & 2 & O.9.Allah kızmasın diye & 1 & (nev $(08)$ \\
\hline & & & O.10.İstersek & & Özgürlük (O10) \\
\hline \multirow{4}{*}{$\begin{array}{l}\text { Nazik } \\
\text { davranılmazsa } \\
\text { neler olur? } \\
\text { (P) }\end{array}$} & P.1.Arkadașlık biter & 7 & P.5.Zarar verebiliriz & 2 & Uyum (P1,P7) \\
\hline & P.2.Bize kızarlar & 6 & P.6.Bizi döverler & 2 & Suç-Ceza \\
\hline & P.3.Bize küserler & 4 & P.7.Kötü şeyler olur & 2 & \\
\hline & P.4.İnsanlar üzülür & 3 & P.8.Bizi sevmezler & 2 & İyilik (P4,P5) \\
\hline
\end{tabular}

Tablo 6' da görüldüğü gibi çocukların nezaket değeri ile ilgili sorulara verdiği cevaplara ilişkin kavramlar kategorize edilmiştir. "Nazik olmak ne demektir?" Sorusuna çocukların verdikleri cevaplardan yola çıkılarak oluşturulan kodlardan iyilik ve uyum temaları oluşturulmuştur. Çocukların büyük bir kısmı uyum teması altındaki kodlar olan "kibar olmak", "uslu durmak", "güzel ve yavaş konuşmak", "kaba olmamak", "dövmemek" ve "aşık olmak" anlamına gelen cevaplar vermiştir. Çocukların az bir kısmı ise iyilik teması altındaki kodlar olan "güzel davranmak" ve "paylaşmak" anlamına gelen ifadeler kullanmıştır. Verilen cevaplardan bazıları doğrudan şu şekildedir:

Ç.13: "Kibar olmak demektir. Güzel davranmaktır." (N.2., N.3.)

Ç.19: "İnsanların en özel süt kaynağıdır." (N.1.)

Ç.18: "Kırılmaması içindir." (N.3., N.6.)

Ç.16: "Aş1k olunca şey olur, aşıısan öyle davranmak..." (N.9.)

Nezaket değerine ilişkin "Niçin nazik davranılmalıdır?" Sorusuna çocukların verdikleri cevaplardan yola çıkılarak oluşturulan kodlardan suç-ceza, çıkar, iyilik, uyum, görev ve özgürlük temaları oluşturulmuştur. Çocukların bir kısmı çıkar teması altındaki kodlar olan "saygı duymaları için", "paylaşmak için" ve "bize küsmesinler diye" anlamına gelen cevaplar vermiştir. Çocukların az bir kısmı ise suç-ceza teması altındaki kodlar olan "bize kızmasınlar diye" ve "Allah kızmasın diye" anlamına gelen ifadeler kullanmıştır. Verilen cevaplardan bazıları doğrudan şu şekildedir:

Ç.20: "Sayg1 duymaları için..." (O.4.)

Ç.5 : "Bize kızmasınlar diye, okuldan atılmayalım diye..." (O.2.)

Ç.7: "Düzgün davranınca güzel davranışlar olur." (O.8.)

Nezaket değerine ilişkin "Nazik davranılmazsa neler olur?" Sorusuna çocukların verdikleri cevaplardan yola çıkılarak oluşturulan kodlardan uyum, suç-ceza, çıkar ve iyilik temaları oluşturulmuştur. Çocukların bir kısmı uyum teması 
altındaki kodlar olan “arkadaşlık biter" ve "kötü şeyler olur” anlamına gelen cevaplar vermiştir. Çocukların bir kısmı ise suç-ceza teması altındaki kodlar olan “bize kızarlar" ve "bizi döverler” anlamına gelen ifadeler kullanmıştır. Verilen cevaplardan bazıları doğrudan şu şekildedir:

Ç.3: "Üzülürler, evlerine giderler, hiç yardım etmezler.” (P.1., P.3., P.4.)

Ç.2: "Arkadaşlı̆̆ımız uzun sürmez." (P.1.)

Ç.17: "Kötü olur, döverler, canımız çok yanar." (P.6., P.7.)

Ç.12: "Bizi sevmez, pis kız derler, oynamazlar.” (P.1., P.8.)

Tablo 7: Okul öncesi dönem çocuklarının arkadaşlık değeri ile ilgili görüşlerinden oluşturulan kodlar ve temalar

\begin{tabular}{|c|c|c|c|c|c|}
\hline Sorular & Kodlar & $\mathrm{F}$ & Kodlar & $\mathrm{F}$ & Temalar \\
\hline $\begin{array}{l}\text { Arkadaşlık } \\
\text { ne demek- } \\
\text { tir? } \\
\text { (R) }\end{array}$ & $\begin{array}{l}\text { R.1.Paylaşma-yar- } \\
\text { dım } \\
\text { R.2.Oyun oynamak } \\
\text { R.3.El ele tutuşmak } \\
\text { R.4.Sevmek } \\
\text { R.5.Arkadaşım } \\
\text { R.6.Uzun sürer }\end{array}$ & $\begin{array}{l}9 \\
8 \\
5 \\
5 \\
4 \\
3\end{array}$ & $\begin{array}{l}\text { R.7.Anlaşmak } \\
\text { R.8.Yanında olmak } \\
\text { R.9.Eğlenmek } \\
\text { R.10.Mutluluk } \\
\text { R.11.Kanka }\end{array}$ & $\begin{array}{l}2 \\
2 \\
2 \\
1 \\
1\end{array}$ & $\begin{array}{l}\text { İyilik (R1,R8) } \\
\text { İhtiyaç (R2,R4,R9,R10) } \\
\text { Uyum (R3,R5,R6,R7,R11) }\end{array}$ \\
\hline $\begin{array}{l}\text { Nelerle } \\
\text { arkadaşlık } \\
\text { yapılabilir? } \\
\text { (S) }\end{array}$ & $\begin{array}{l}\text { S.1.Arkadaşlarımla } \\
\text { S.2.Insanlarla } \\
\text { S.3.Oyuncaklarla } \\
\text { S.4.Hayvanlarla } \\
\text { S.5.Çocuklarla } \\
\text { S.6.Büyüklerle }\end{array}$ & $\begin{array}{l}11 \\
6 \\
6 \\
4 \\
4 \\
4\end{array}$ & $\begin{array}{l}\text { S.7.Doğa (su-gökyüzü-a- } \\
\text { ğaç) } \\
\text { S.8.Herkesle } \\
\text { S.9.Aynı yaştakilerle } \\
\text { S.10.Bitkilerle } \\
\text { S.11.Paylaşanlarla } \\
\text { S.12.Yaramaz olmayanlarla }\end{array}$ & $\begin{array}{l}3 \\
2 \\
2 \\
1 \\
1 \\
1\end{array}$ & $\begin{array}{l}\text { Uyum } \\
\text { (S1,S2,S5,S6,S8,S9,S12) } \\
\text { Ç1kar (S11) } \\
\text { İhtiyaç (S3,S7) } \\
\text { Özgürlük (S4,S10) }\end{array}$ \\
\hline $\begin{array}{l}\text { Arkadaşlar } \\
\text { birbirine } \\
\text { nasıl davra- } \\
\text { nır? } \\
\text { (T) }\end{array}$ & $\begin{array}{l}\text { T.1.Güzel-İyi } \\
\text { T.2.Çok nazik } \\
\text { T.3.Kavga etmez }\end{array}$ & $\begin{array}{l}16 \\
4 \\
4\end{array}$ & $\begin{array}{l}\text { T.4.Düzgün konuşur } \\
\text { T.5.Paylaşır } \\
\text { T.6.Severler }\end{array}$ & $\begin{array}{l}3 \\
2\end{array}$ & $\begin{array}{l}\text { Uyum }(\mathrm{T} 1, \mathrm{~T} 2, \mathrm{~T} 3, \mathrm{~T} 4) \\
\text { Ç1kar (T5,T6) }\end{array}$ \\
\hline
\end{tabular}

Tablo 7'de görüldüğü gibi çocukların arkadaşlık değeri ile ilgili sorulara verdiği cevaplara ilişkin kavramlar kategorize edilmiştir. "Arkadaşlık ne demektir?" Sorusuna çocukların verdikleri cevaplardan yola çıkılarak oluşturulan kodlardan iyilik, ihtiyaç ve uyum temaları oluşturulmuştur. Çocukların bir kıs$\mathrm{m}$ iyilik teması altındaki kodlar olan "paylaşma-yardım" ve "yanında olmak" anlamına gelen cevaplar vermiştir. Çocukların bir kısmı ise ihtiyaç teması altındaki kodlar olan "oyun oynamak", "sevmek", "eğlenmek", "mutluluk”; diğer bir kısmı ise uyum teması altındaki kodlar olan "el ele tutuşmak", "arkadaşım", "uzun sürer" ve "anlaşmak" anlamına gelen ifadeler kullanmıştır. Verilen cevaplardan bazıları doğrudan şu şekildedir:

Ç.12: "Eğlenmek demektir." (R.9.)

Ç.9: “......., ....... ...... ile parkta, evde, okulda oyun oynuyoruz.” (R.2., R.5.)

Ç.13: "Mutlu olmak, sayg1 duymak demektir." (R.7., R.10.) 
Arkadaşlık değerine ilişkin “nelerle arkadaşlık yapılabilir?” Sorusuna çocukların verdikleri cevaplardan yola çıkılarak oluşturulan kodlardan uyum, çıkar, ihtiyaç ve özgürlük temaları oluşturulmuştur. Çocukların büyük bir kısmı uyum teması altındaki kodlar olan "arkadaşlarımla", "insanlarla", "çocuklarla", "büyüklerle", "herkesle", "aynı yaştakilerle" ve "yaramaz olmayanlarla" anlamına gelen cevaplar vermiştir. Çocukların bir kısmı ise ihtiyaç teması altındaki kodlar olan "oyuncaklarla" ve "doğayla", diğer bir kısmı özgürlük teması altındaki kodlar olan "hayvanlarla" ve "bitkilerle" anlamına gelen ifadeler kullanmıştır. Verilen cevaplardan bazıları doğrudan şu şekildedir:

Ç.18: "İkimiz de aynı boyda ve yaşta olursak... Bi de hayvanlarla... İnsana benzeyen oyuncakla da arkadaş olunur." (S.3., S.4., S.9.)

Ç.16: "Arkadaşlarımla... Diğerleri yaramaz çünkü.” (S.1., S.12.)

Ç.6: "Bitkilerle, insanlarla..." (S.2., S.10.)

Ç.5 "İnsanlarla... Ama bazı kişiler hayvanlarla da yapabiliyor." (S.2., S.4.)

Arkadaşlık değerine ilişkin "Arkadaşlar birbirine nasıl davranır?" Sorusuna çocukların verdikleri cevaplardan yola çıkılarak oluşturulan kodlardan uyum ve çıkar temaları oluşturulmuştur. Çocukların büyük bir kısmı uyum teması altındaki kodlar olan "güzel-iyi”, "ç̧ok nazik”, "kavga etmez” ve "düzgün konuşur" anlamına gelen cevaplar vermiştir. Çocukların küçük bir kısmı ise çıkar teması altındaki kodlar olan "paylaşır" ve "severler" anlamına gelen ifadeler kullanmıştır. Verilen cevaplardan bazıları doğrudan şu şekildedir:

Ç.10: "Güzelce davranılır. Çünkü kötü davranılırsa üzülür onlar.” (T.1., T.4.)

Ç.3: "Paylaşarak davranır." (T.5.)

Ç.1: "Çok nazik davranır." (T.2.)

Ç.18: "Güzel... kavga etmeden..." (T.1., T.3.)

Tablo 8: Okul öncesi dönem çocuklarının dürüstlük değeri ile ilgili görüşlerinden oluşturulan kodlar ve temalar

\begin{tabular}{|c|c|c|c|c|c|}
\hline Sorular & Kodlar & $\mathrm{F}$ & Kodlar & $\mathrm{F}$ & Temalar \\
\hline $\begin{array}{l}\text { Dürüstlük ne } \\
\text { demektir? } \\
\text { (U) }\end{array}$ & $\begin{array}{l}\text { U.1.Bilmiyorum } \\
\text { U.2.Kurallara uymak } \\
\text { U.3.Düzgün davran- } \\
\text { mak } \\
\text { U.4.Saygılı olmak }\end{array}$ & $\begin{array}{l}13 \\
5 \\
5 \\
3\end{array}$ & $\begin{array}{l}\text { U.5.Korkmamak } \\
\text { U.6.Barışmak } \\
\text { U.7.Arkadaşlık } \\
\text { U.8.Kibar olmak }\end{array}$ & $\begin{array}{l}2 \\
2 \\
2 \\
1\end{array}$ & $\begin{array}{l}\text { Uyum } \\
\text { (U3,U4,U6,U7,U8) } \\
\text { Cesaret (U5) } \\
\text { Görev (U2) }\end{array}$ \\
\hline $\begin{array}{l}\text { Dürüst olmayan } \\
\text { davranışlar } \\
\text { nelerdir? } \\
\text { (V) }\end{array}$ & $\begin{array}{l}\text { V.1.Güzel davranma- } \\
\text { mak } \\
\text { V.2.Bilmiyorum } \\
\text { V.3.Kurallara uyma- } \\
\text { mak } \\
\text { V.4.Yaramazlık } \\
\text { V.5.Yapılması istenme- } \\
\text { yenler }\end{array}$ & $\begin{array}{l}11 \\
7 \\
5 \\
4 \\
3\end{array}$ & $\begin{array}{l}\text { V.6.Kızmak } \\
\text { V.7.Paylaşmamak } \\
\text { V.8.Kavga etmek } \\
\text { V.9.Üzmek } \\
\text { V.10.Atatürk gibi dav- } \\
\text { ranmamaktır }\end{array}$ & $\begin{array}{l}2 \\
2 \\
2 \\
1 \\
1\end{array}$ & $\begin{array}{l}\text { Uyum (V1,V4,V8) } \\
\text { Görev (V3,V5,V10) } \\
\text { Tolerans (V6) } \\
\text { Çıkar (V7) } \\
\text { İyilik (V9) }\end{array}$ \\
\hline
\end{tabular}




\begin{tabular}{llllll}
\hline & & & Y.6.S1kılırız & & Suç-Ceza (Y2) \\
Dürüst davra- & Y.1.Bilmiyorum & 8 & Y.7.Kavga çıkabilir & 2 & Çıkar (Y3,Y8) \\
nılmadı̆̆ı zaman & Y.2.Bize kızarlar & 6 & Y.8.Bize nazik davran- & 2 & Uyum \\
neler olur? & Y.3.Bizi sevmezler & 5 & mazlar & 2 & (Y4,Y6,Y7,Y9) \\
(Y) & Y.4.Kötü olur & 4 & Y.9.Arkadaşlık uzun & 2 & İyilik (Y5) \\
& Y.5.İnsan yaralanır & 3 & sürmez & 1 & Görev (Y10) \\
& & & Y.10.Allah üzülür & & \\
\hline
\end{tabular}

Tablo 8'de görüldüğü gibi çocukların dürüstlük değeri ile ilgili sorulara verdiği cevaplara ilişkin kavramlar kategorize edilmiştir. "Dürüstlük ne demektir?" Sorusuna çocukların verdikleri cevaplardan yola çıkılarak oluşturulan kodlardan uyum, cesaret ve görev temaları oluşturulmuştur. Çocukların çoğunluğu uyum teması altındaki kodlar olan "düzgün davranmak", "saygılı olmak", "barışmak", "arkadaşl1k" ve "kibar olmak" anlamına gelen cevaplar vermiştir. Çocukların az bir kısmı cesaret teması altındaki kod olan "korkmamak"; yine az bir kısmı görev teması altındaki kod olan "kurallara uymak" anlamına gelen ifadeler kullanmıştır. Verilen cevaplardan bazıları doğrudan şu şekildedir:

Ç.18: "Bir arkadaşım oyun oynarken kafanı suya sok derse sokarsan bu dürüstlüktür." (U.7.)

Ç.10: "Hırsızlardan korkmamak... Yalan söyleyen arkadaşlara inanmamak lazım. Çoğu kişilere inanmamak gerek.” (U.8., U.10.)

Ç.4: "Düzgün davranmak..." (U.3.)

Dürüstlük değerine ilişkin "Dürüst olmayan davranışlar nelerdir?" Sorusuna çocukların verdikleri cevaplardan yola çıkılarak oluşturulan kodlardan uyum, görev, tolerans, çıkar ve iyilik temaları oluşturulmuştur. Çocukların yarısından fazlası uyum teması altındaki kodlar olan "güzel davranmamak", "yaramazlık" ve "kavga etmek" anlamına gelen cevaplar vermiştir. Çocukların bir kısmı görev teması altındaki kodlar olan "kurallara uymamak", "yapılması istenmeyenler" ve "Atatürk gibi davranmamak", az bir kısmı tolerans teması altındaki kod olan "kızmak" anlamına gelen ifadeler kullanmıştır. Verilen cevaplardan bazıları doğrudan şu şekildedir:

Ç.17: "Yapılması istenmeyen şeyler..." (V.5.)

Ç.19: "Atatürk gibi olmayan şeyler..." (V.10.)

Ç.13: "Kötü davranışlardır.” (V.1., V.3., V.4., V.5., V.8., V.9.)

Ç.15: "Düzgün durmamak..." (V.1., V.3., V.4., V.5.)

Dürüstlük değerine ilişkin "Dürüst davranılmadığında neler olur?” Sorusuna çocukların verdikleri cevaplardan yola çıkılarak oluşturulan kodlardan suç-ceza, çıkar, uyum, iyilik ve görev temaları oluşturulmuştur. Çocukların bir kısmı suç-ceza teması altındaki kod olan "bize kızarlar" anlamına gelen cevaplar vermiştir. Çocukların bir kısmı çıkar teması altındaki kodlar olan "bizi sevmez- 
ler" ve "bize nazik davranmazlar"; bir kısmı uyum teması altındaki kodlar olan "kötü olur", "sıkılırız", "kavga çıkabilir" ve "arkadaşlık uzun sürmez", az bir kısmı iyilik teması altındaki kod olan "insan yaralanır", 1 tanesi ise görev teması altındaki kod olan "Allah üzülür" anlamına gelen ifadeler kullanmıştır. Verilen cevaplardan bazıları doğrudan şu şekildedir:

Ç.2: “Arkadaşlı̆̆ımız uzun sürmez.” (Y.9.)

Ç.5: "Arkadaşlarımız nazik ve güzel davranmaz." (Y.8.)

Ç.6: "İnsanlar bizimle her gün konuşmaz, tanışmaz." (Y.3., Y.9.)

Ç.18: "Dünya çok sıkıcı olur." (Y.6.)

Tablo 9: Çalışmadaki tüm temalar, temaların bulunduğu sorular, temaların içerdiği değerler, temaların bulunduğu kod sayısı

\begin{tabular}{|c|c|c|c|}
\hline Temalar & $\begin{array}{l}\text { Temayı İçeren } \\
\text { Değerler }\end{array}$ & $\begin{array}{l}\text { Temayı İçeren } \\
\text { Sorular }\end{array}$ & $\begin{array}{l}\text { Bulunduğu } \\
\text { Kod Sayısı }\end{array}$ \\
\hline Uyum & $\begin{array}{l}\text { Sorumluluk, Paylaşma, } \\
\text { Yardımseverlik, } \\
\text { Saygı, Nezaket, Arkadaşlık, } \\
\text { Dürüstlük }\end{array}$ & $\begin{array}{l}\text { A, B, C, D, F, H, I, J, K, L, N, } \\
\text { O, P, R, S, T, U, V, Y }\end{array}$ & 64 \\
\hline İyilik & $\begin{array}{l}\text { Sorumluluk, Paylaşma, } \\
\text { Yardımseverlik, } \\
\text { Saygı, Nezaket, Arkadaşlık, } \\
\text { Dürüstlük }\end{array}$ & $\begin{array}{l}\text { C, D, E, F, G, H, I, J, K, L,M, } \\
\text { N, O, P, R, V, Y }\end{array}$ & 42 \\
\hline Çıkar & $\begin{array}{l}\text { Sorumluluk, Paylaşma, } \\
\text { Yardımseverlik, } \\
\text { Saygı, Nezaket, Arkadaşlık, } \\
\text { Dürüstlük }\end{array}$ & $\mathrm{D}, \mathrm{F}, \mathrm{G}, \mathrm{J}, \mathrm{M}, \mathrm{O}, \mathrm{P}, \mathrm{S}, \mathrm{T}, \mathrm{V}, \mathrm{Y}$ & 23 \\
\hline Görev & $\begin{array}{l}\text { Sorumluluk, Paylaşma, } \\
\text { Yardımseverlik, } \\
\text { Saygı, Nezaket, Dürüstlük }\end{array}$ & $\mathrm{A}, \mathrm{B}, \mathrm{C}, \mathrm{F}, \mathrm{H}, \mathrm{L}, \mathrm{O}, \mathrm{U}, \mathrm{V}, \mathrm{Y}$ & 19 \\
\hline İhtiyaç & Sorumluluk, Paylaşma, Arkadaşlık & $\mathrm{A}, \mathrm{C}, \mathrm{E}, \mathrm{R}, \mathrm{S}$ & 13 \\
\hline Suç-Ceza & $\begin{array}{l}\text { Sorumluluk, Paylaşma, Sayg1, } \\
\text { Nezaket, Dürüstlük }\end{array}$ & $\mathrm{D}, \mathrm{F}, \mathrm{M}, \mathrm{O}, \mathrm{P}, \mathrm{Y}$ & 10 \\
\hline Özgürlük & Paylaşma, Nezaket, Arkadaşlık & $\mathrm{E}, \mathrm{F}, \mathrm{O}, \mathrm{S}$ & 5 \\
\hline Hürmet & Sayg1 & $\mathrm{K}, \mathrm{L}$ & 3 \\
\hline Çalışma & Sorumluluk & A & 2 \\
\hline Tolerans & Sayg1, Dürüstlük & $\mathrm{K}, \mathrm{V}$ & 2 \\
\hline Temkin & Sorumluluk & $\mathrm{D}$ & 1 \\
\hline Şefkat & Sayg1 & $\mathrm{L}$ & 1 \\
\hline Cesaret & Dürüstlük & $\mathrm{U}$ & 1 \\
\hline
\end{tabular}

Tablo 9'da araştırma kapsamında oluşturulan kodlardan uyum, iyilik, çıkar, görev, ihtiyaç, suç-ceza, özgürlük, hürmet, çalışma, tolerans, şefkat ve cesaret temalarına ulaşıldığı görülmektedir. Buna göre uyum, iyilik ve çıkar temaları araştırma kapsamındaki tüm değerlerde bulunmaktadır. Görev teması arkadaşlık dışındaki, suç-ceza teması ise yardımseverlik ve arkadaşlık dışındaki değerlerde bulunmamaktadır. İhtiyaç teması sorumluluk, paylaşma, arkadaşlık; özgürlük teması paylaşma, nezaket, arkadaşlık; tolerans teması saygı ve dürüstlük 
değerlerinde bulunmaktadır. Hürmet ve şefkat temaları saygı, çalışma ve temkin temaları sorumluluk, cesaret teması ise dürüstlük değerinde bulunmaktadır.

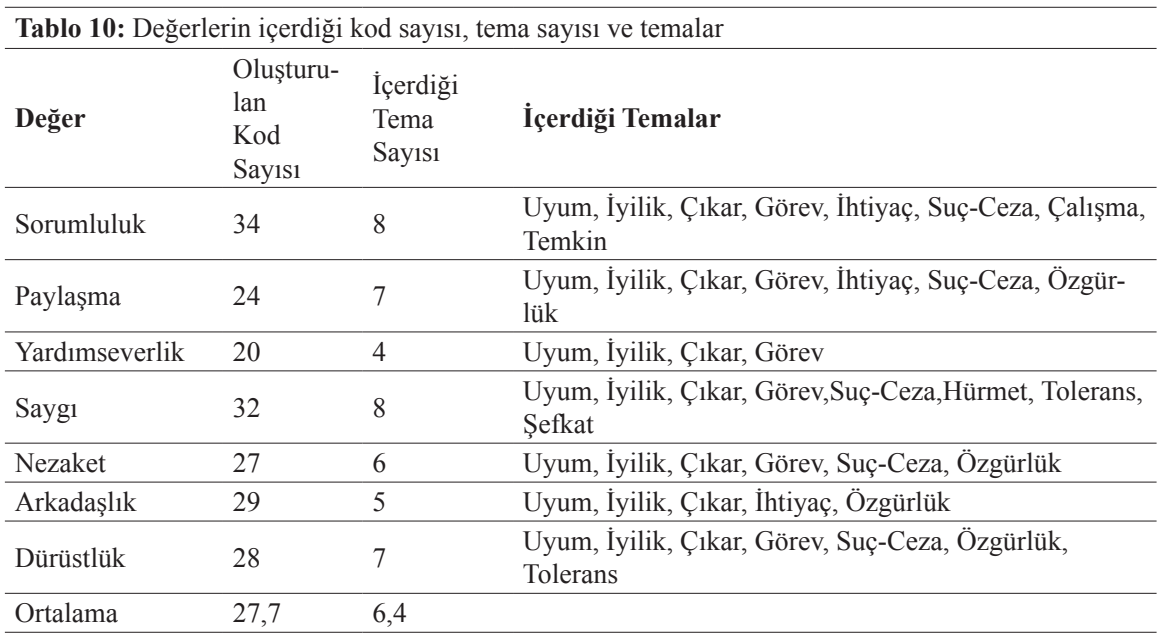

Kodlardan ulaşılan 13 temanın çalışma kapsamındaki değerlerde bulunma sayılarına bakıldığında; sorumluluk ve saygı değerlerinde 8 , paylaşma ve dürüstlük değerlerinde 7 , nezaket değerinde 6 , arkadaşlık değerinde 5 ve yardımseverlik değerinde 4 temanın yer aldığ görülmektedir. Değerlerin tema ortalamasının ise 6,4 olduğu görülmektedir.

\section{Tartışma ve Sonuç}

Çalışmanın odağında olan okul öncesi dönem çocukları bilişsel seviye olarak işlem öncesi dönemde yer almaktadır. Piaget (1952) bu süreçten sonra somut işlemler döneminin başladığını ifade etmektedir. Değerler gibi somutlaştırılması zor kavramları erken çocukluk dönemindeki çocukların algılamakta ve tanımlamakta zorlanması son derece olağan bir durumdur. Bu nedenle ebeveyn veya öğretmenlerin, Trawick-Smith'in (2014) de belirtiği gibi, değerlerle ilgili öğrenme yaşantılarını somut olaylarla ve nesnelerle desteklemesi gerekir. Çocuklara değerlerin kazandırılması için ebeveynlerin de kaliteli vakit geçirmenin önemini kavraması ve bu bağlamda eylemler gerçekleştirmesi önemlidir. Günümüzde ailedeki çocuk sayısının azalmasıyla, çocuğa ayrılan vaktin artması beklenirken, bu durum değerlerin edindirilmesinde avantaj olarak görülebilir.

Çocukların algılama ve tanımlamalarını etkileyen önemli hususlardan biri öğretmenin iletişiminde değer kavramlarına yer vermesi veya etkinliklerinde ele almasıdır. Özellikle formal eğitimde bu şekilde sistematik bir değerler eğitimi 
verilmesi çocukların algılama ve tanımlamalarını doğrudan etkiler. Tarkoçin ve arkadaşlarının (2013) yaptığı araştırmada okul öncesi öğretmenlerinin etkinlikleri sırasında gerçekleşen iletişimlerinde 12 değer kullandıkları belirtilmiştir. $\mathrm{Bu}$ çalışmada ise kullanılan değerlerden arkadaşlık dışındaki değerler bu 12 değer arasındadır.

Değerler eğitimi ile ilgili öğrenci/çocukları odağa alan çalışmalara bakıldığında genellikle ilkokul, ortaokul, lise ve üniversite öğrencilerine odaklanıldığı görülmektedir. Bu çalışmaya yakın olması bakımından ilkokul dönemine yönelik çalışmaların incelenmesi, bulguların karşılaştırılması açısından önemlidir. Deveci ve Ay'ın (2009) araştırmasında 5. sınıfta okuyan çocukların tutmuş olduğu günlüklerdeki ifadeler değerleri büyük ölçüde doğru algıladıkları sonucunu ortaya koymaktadır. İngiltere'de Such ve Walker (2004) tarafindan yapılan bir araştırmada, 9 ve 10 yaşlarındaki ilkokul çocukları ile çalışılmış, sorumluluğun günlük yaşamın vazgeçilmez bir parçası olduğu ve en önemli sorumlulukların dürüstlük ile adil olma olduğu sonucu ortaya çıkmıştır. 10-13 yaşları arasındaki ilkokul çocukları üzerinde yaptıkları araştırmada Yılmaz, Göçen ve Y1lmaz (2013) sokakta çalışmayan çocukların bilimsellik, dürüstlük, estetik ve sevgi değerlerini daha çok vurguladıkları sonucuna ulaşmıştır. Kurnaz, Çiftçi ve Karapazar (2011) üstün zekalı ve yetenekli çocuklarla yaptıkları araştırmada daha ileri yaştaki çocukların değerleri algılamasının ve bu değerlerle ilgili metafor üretmesinin daha sık rastlanan bir bulgu olduğu sonucuna ulaşmıştır. $\mathrm{Bu}$ sonuçlar doğrultusunda, değerlerle ilgili algının oluşmasında çevrenin, yaşın ve zekanın etkili olduğu söylenebilir.

Okul öncesi dönem çocuklarına yönelik yapılan çalışmalarda büyük yaştaki çocukların küçüklere oranla değerlerle ilgili daha belirgin algılama ve tanımlama yapabildikleri yukarıda belirtilen araştırmalarda görülmektedir. Bu bağlamda küçük yaş grubuna yönelik araştırmalar da incelendiğinde yapılan bir çalışmada Yukay-Yüksel ve diğerleri (2015) 4-5 yaş çocuklarının değerlerle ilgili ifadeleri kullanmadığı, 5-6 yaş çocuklarının ise değerlere yönelik kavram ve ifadeleri dile getirdiği sonucuna ulaşmıştır. Tek bir değere odaklanılan Sapsağlam'ın (2017) çalışmasında da 3-6 yaş arası çocuklara sorumluluk değeriyle ilgili çizim yapmaları yönergesi verilerek değer algıları tespit edilmeye çalışılmıştır. Sonuçta çocukların yaşları ilerledikçe değerle ilgili daha ayrıntılı ve olumlu bir algılamaya sahip oldukları saptanmıştır. Bu sonuçlar gösteriyor ki okul öncesi dönemin son evresi olan 5-6 yaş grubundaki çocuklar değerlerle ilgili algılama ve tanımlama davranışı sergileyebilmektedir. Bu çalışmanın 
bulguları da benzer çalışma ve araştırmaların sonuçlarını destekler niteliktedir.

Erken çocukluk dönemi çocuklarının bireysel ve çevresel farklılıkları dikkate alındığında tamamının bir değer kavramıyla ilgili aynı cevap üzerinde mutabık kalmaması normal kabul edilebilir. Ancak 'arkadaşların birbirine güzel-iyi davranması' ile 'oyuncağın paylaşılması' cevaplarında olduğu gibi kalıp cümleler yoğunlukla görülebilmektedir. Bazı değerlerde, örneğin sorumluluk gibi, algılama ve tanımlama aynı yönde veya kavram üzerinde yığılma görülebilir. Bununla birlikte bu çalışmadaki "yardımseverlik ve "nezaket" değerlerindeki bulgularda görüldüğü gibi tanımlamalar aynı yön veya kavram üzerinde toplanmayıp dağınıklık görülebilir. Günindi'nin (2015) çalışmasında sevgi değerine yönelik tanımlamalar aile, diğer insanlar, bitkiler, hayvanlar, cansız varlıklar, binalar/araçlar, mutluluk verici semboller, yiyecekler, doğa olayları ve diğer başlıkları altında bir dağılım sergilemiştir.

Okul öncesi dönem çocukları değer kavramıla ilgili sorulan sorulara o kavramı tanımlamak yerine başka bir değer kavramını kullanarak ya da somut bir davranışı örnek göstererek cevap vermiştir. Benzer durum Tatlı ve Güngör-Aytar'ın (2017) çalışmasında da görülmüştür. Çalışmada verilen değerler eğitimi sonrasında çocuklara bu kavramlarla ilgili yaptırılan resimleri ifade etmeleri istenmiştir. Çocukların resimlerinde yardımseverlik, merhamet, sevgi, hoşgörü, vatanseverlik, paylaşmak, çalışkanlık, iyilik, tutumluluk ve dürüstlük değerleriyle ilgili kullandıkları metaforları ortaya çıkarılmıştır. En çok kullanılan metaforların yardımseverlik değeri için iyilik yapmak ve kötülükten kurtarmak; merhamet değeri için anne babanın çocuğunu sevmesi; sevgi değeri için hediye ve çiçek vermek; vatanseverlik değeri için Dünyay1-Türkiye'yi korumak; hoşgörü değeri için anlayışlı olmak; paylaşma değeri için eşyalarımızı birilerine vermek; çalışkanlık değeri için derslerimize çok çalışmak; iyilik değeri için insanlara güzel davranmak ve kötü davranmamak; tutumluluk değeri için para biriktirmek; dürüstlük değeri için doğruları söylemek ve yalan söylememek olduğu tespit edilmiştir. İlkokul 1. ve 4. sınıf öğrencileri ile yapılan bir çalışmada Tozduman-Yaral1, Özkan ve Güngör-Aytar (2016) sevgi değerinin başka değerler kullanılarak tanımlanmaya çalışıldığı sonucuna ulaşmıştır. Bir değerin algılanmasında ve tanımlanmasında diğer bir değerin kullanılması dikkat çekici bir sonuç olarak görülebilir. Fakat çocukların ifade edici dil becerilerinin yeterince gelişmediği dikkate alındığında bu durum normal karşılanmalıdır.

Araştırma kapsamındaki yedi değerden beşinde çocukların cevapları bu kavramları doğru algıladıkları ve tanımladıklarını göstermektedir. İki değerde ise 
kavramların büyük oranda algılanamadığı ve yanlış algılandığı anlaşılmaktadır. Çocukların dürüstlük ve nezaket değerleriyle ilgili tanımlamalarında yüksek oranda bilmiyorum gibi cevapların çıkması, ayrıca yanlış algıladıklarına dair cevapların da olması bu değerlerle ilgili çevrelerinden yeterince uyaran almadıklarına işaret olabilir. Çocukların bu değerlerle ilgili somut davranışları yeterince görememesi, bu durum kapsamındaki yaşantılarla sıkça karşılaşmaması ve formal bir değerler eğitimi almaması muhtemel nedenler olarak sayılabilir. Verilerin çocukların okul öncesi eğitim kurumuna başladıktan iki ay sonra alınması ilgili alg1 ve tanımlamaların aile kaynaklı olduğu düşüncesini kuvvetlendirmektedir. Fakat kesin konuşabilmek için bu durumun ailede alınan informal eğitimden mi yoksa kurumlarda alınan formal eğitimden mi kaynaklandığına dair araştırmalara ihtiyaç duyulmaktadır.

Yavuzer (2000) sorumluluğu erken çocukluk döneminden itibaren çocuğun yaş1, cinsiyeti ve gelişim seviyesine uygun davranış sergileyerek üstüne düşen görevleri yerine getirmesi olarak tanımlamıştır. Güncel Türkçe Sözlük’te ise kişinin kendi davranışlarını veya kendi yetki alanına giren herhangi bir olayın sonuçlarını üstlenmesi olarak tanımlanan sorumluluğu; çalışma grubundaki çocuklar, bir şeyi yerine getirmek, düzenli derli toplu olmak, bilmiyorum, düzgün davranmak, yorulmak, işçi olmak, söz dinlemek, kendine dikkat etmek, oyun oynamak şeklinde kodlanan birçok ifadeyle tanımlamışlardır. Katılımcıların cevaplarından elde edilen kodlardan uyum, iyilik, çıkar, görev, ihtiyaç, suç-ceza, çalışma, temkin olmak üzere sekiz tema oluşturulmuştur. Bu çıkarımların ebeveynlerin yansıttığ rol ve davranışlarla doğrudan ilişkili olduğu söylenebilir. Ailedeki sorumluluk söylemleri doğrultusunda işitilen yönergelerin, çocukların sorumluluk kavramına yönelik algı ediniminde etkili olduğu sonucu çıkarılabilir.

Paylaşma herhangi bir karşılık beklemeden somut veya soyut olan bir şeyi içsel bir motivasyonla alma veya verme durumu şeklinde tanımlanabilir. Güncel Türkçe Sözlük’te aralarında bölüşmek, pay etmek olarak tanımlanan paylaşmayı, çocuklar başkasına vermek, güzel bir şey, oyuncakları başkasıyla oynamak, eğlenmek, istediğini yapabilmek, kardeş olmak, ikiye bölmek, bilmiyorum şeklinde kodlanan birçok ifadeyle tanımlamışlardır. Katılımcıların cevaplarından elde edilen kodlardan uyum, iyilik, çıkar, görev, ihtiyaç, suç-ceza, özgürlük olmak üzere yedi tema oluşturulmuştur. Bu çıkarımlar paylaşma değeri ile ilgili çocukların tanımlamalarının metaforlar ve davranış kalıplarıyla oluştuğunu ve algılamalarının da doğru olduğunu gösterebilir. Ayrıca çocukların daha önce deneyimledikleri, iletişim ortamlarında gerçekleştirmiş oldukları paylaşma davra- 
nışlarını bu araştırma kapsamındaki soruların cevabı niteliğinde dile getirdikleri ifade edilebilir.

Kolukısa, Oruç, Akbaba ve Dündar (2008) yardımseverliği bireyin kendi imkanları ve yeterliliklerini başkaları için sarf etmesi olarak tanımlamaktadır. Güncel Türkçe Sözlük’te ise kendi gücünü ve imkânlarını başka birinin iyiliği için kullanmayı sevme olarak tanımlanan yardımseverliği çocuklar beraber yapmak, birlik olmak, düşen arkadaşımı kaldırmak, güzel bir şey, anneme yemekte yardım etmek, yapamayan birinin yerine yapmak, herkese yardım etmek, iş, destek olmak, hasta birini hastaneye götürmek şeklinde kodlanan birçok ifadeyle tanımlamışlardır. Katılımcıların cevaplarından elde edilen kodlardan uyum, iyilik, çıkar ve görev olmak üzere dört tema oluşturulmuştur. Herhangi bir değerler eğitimi programına alınmayan çocukların bu ifadeleri, kavramın çoğunlukla doğru algılandığını gösterir. Çocukların vermiş oldukları yanıtların günlük yaşamlarında karşılaştıkları yetişkin tutum ve söylemlerinden kaynaklandığı söylenebilir. Bir yetişkinin yardım etme ya da yardımseverlik değerine ilişkin gerçekleştirmiş olduğu her türlü hal-hareket ve söylem, çocukların bu kavramla ilgili algıyı bu doğrultuda edinmesine zemin hazırlamaktadır. Ayrıca içinde bulunduğu gelişim dönemi itibariyle çocukta çıkarcı eğilimin görüldüğü söylenebilir.

Dickert (2009) saygıyı belirli bir nesne veya kişi hakkında neyin değerli veya önemli olduğunu takdir etme, böyle bir değerlemenin kişinin kendi davranıŞına yansıyan kısıtlamaları veya talepleri tanıma ve bu tanınırlığı ifade eden bir şekilde hareket etme olarak tanımlamıştır. Bununla birlikte saygı kavramına yönelik oldukça fazla ve farklı tanımlamanın bulunduğu literatürde, üzerinde tam olarak uzlaşılmış bir tanımlamanın olmadığı ifade edilebilir. Güncel Türkçe Sözlük’te değeri, üstünlüğü, yaşlılığı, yararlılı̆̆ı, kutsallığı dolayısıyla bir kimseye, bir şeye karşı dikkatli, özenli, ölçülü davranmaya sebep olan sevgi duygusu, hürmet olarak tanımlanan saygıyı çocuklar saygılı davranmak, güzel bir şey, büyüklere yardım etmek, uslu davranmak, kötü konuşmamak, kızmamak, engellilere yardım etmek, güzel konuşmak, gösterilen bir şey, sözünü tutmak şeklinde kodlanan birçok ifadeyle tanımlamışlardır. Katılımcıların cevaplarından elde edilen kodlardan uyum, iyilik, çıkar, görev, suç-ceza, hürmet, tolerans ve şefkat olmak üzere sekiz tema oluşturulmuştur. Bu çıkarımlardan yola çıkılarak çocukların saygıyı etkileşimde oldukları kişilerden görerek algıladıkları sonucuna ulaşılabilir

Ryan (2012) nezaketi, niyet ve iyilik arası karşılıklı içsel kabulün kalitesi olarak tanımlamıştır. Güncel Türkçe Sözlük’te başkalarına karşı saygılı ve incelik- 
le davranma, incelik, naziklik olarak tanımlanan nezaketi çocuklar bilmiyorum, güzel davranmak, kibar olmak, uslu durmak, güzel ve yavaş konuşmak, kaba olmamak, dövmemek, paylaşmak, aşık olmak şeklinde kodlanan birçok ifadeyle tanımlamışlardır. Katılımcıların cevaplarından elde edilen kodlardan uyum, iyilik, çıar, görev, suç-ceza ve özgürlük olmak üzere altı tema oluşturulmuştur. Çocukların birçoğunun bu değerle ilgili tanımlama yapamamaları, bir kısmının ise yanlış metaforlarla beraber kullanması algılama ve tanımlamada eksiklik veya sorunlar olduğunu göstermektedir. Çıkar, suç-ceza ve özgürlük gibi temaların oluşmasının bu durumu desteklediği söylenebilir.

Bukowski, Newcomb ve Hartup (1996) arkadaşlı̆g kişilerin birbirini, ortak şeyleri ve birlikte vakit geçirmeyi sevmesini içeren etkileşim olarak tanımlamıştır. Güncel Türkçe Sözlük'te birbirlerine karşı sevgi ve anlayış gösteren kimselerden her birinin durumu, arkadaşa yakışır davranış, omuzdaşlık olarak tanımlanan arkadaşlığı çocuklar paylaşma-yardım, oyun oynamak, mutluluk, eğlenmek, el ele tutuşmak, anlaşmak, yanında olmak, sevmek, kanka şeklinde kodlanan birçok ifadeyle tanımlamışlardır. Katılımcıların cevaplarından elde edilen kodlardan uyum, iyilik, çıkar, ihtiyaç ve özgürlük olmak üzere beş tema oluşturulmuştur. Çıkarımlar çocukların arkadaşlı̆̆ birbirleriyle vakit geçirdikleri eylemler üzerinden algıladıklarını ve tanımladıklarını göstermektedir. Ayrıca gelişimsel olarak çıkar eğiliminin ve duygusal ihtiyaçların da ön planda olduğu söylenebilir.

Dürüstlük kişinin karşılaştığı olay, durum veya seçme gibi süreçlerde kendi veya başkasının çıkarını gütmeksizin samimi ve doğru bildiği şekilde davranması olarak tanımlanabilir. Güncel Türkçe Sözlük'te sözünde ve davranışlarında doğruluktan ayrılmama durumu olarak tanımlanan dürüstlüğü çocuklar bilmiyorum, kurallara uymak, düzgün davranmak, saygılı olmak, ağzını kapatmak, barışmak, arkadaşlık, korkmamak, kibar olmak şeklinde kodlanan birçok ifadeyle tanımlamışlardır. Katılımcıların cevaplarından elde edilen kodlardan uyum, iyilik, çıkar, görev, suç-ceza, özgürlük ve tolerans olmak üzere yedi tema oluşturulmuştur. Çocukların birçoğunun bu değerle ilgili tanımlama yapamayış1, bazılarının ise yanlış metaforlarla birlikte kullanarak cevap vermesi algılama ve tanımlamada eksiklik veya sorunlar olduğunu göstermektedir. Cevap ve kodlardan iyilik, özgürlük ve tolerans temalarının oluşturulması bu durumun göstergesi olabilir.

Bu çalışmanın sonucu göstermektedir ki; çocuklar pek çok kavramda olduğu gibi değerlerle ilgili algılama ve tanımlamalarını erken çocukluk döneminde 
çevresel uyaranlar, yaşam deneyimleri, ailede konuşulan ifadeler ve gözlemledikleri davranışlar aracılığı ile edinmektedir. Bandura (1977) sosyal öğrenme teorisinde çocukların öğrenme sürecinde çevresiyle etkileşiminin çok önemli bir faktör olduğunu aktarmaktadır. Bu bağlamda değerlerle ilgili istendik davranışların kazandırılmasında çevrenin uygun uyaranlarla organize edilmesi hedefe ulaşmada oldukça önemlidir. Değerler eğitimi ile ilgili program ve içerikler oluşturulurken bu ilkenin göz önünde bulundurulması gerekir.

Erken çocukluk eğitiminde değer eğitimi programlarının veya içeriklerinin hazırlanmasında çocukların bilişsel süreçlerinin daha fazla göz önünde bulundurulması önerilmektedir. Çocukların algılarının hangi kaynaktan ve nasıl etkilendiğine dair farklı disiplinlerden araştırmacıların bulunduğu çalışmalara daha fazla yer verilmelidir. Ayrıca araştırmacılara çocukların katılımcı olduğu çalışmalara daha fazla odaklanması önerilmektedir. Küçük yaştaki çocuklarla araştırma yapma sürecindeki sınırlılıkları aşmak amacıyla daha çok özen ve çalışma gerektiren, aynı zamanda çocukların derinlemesine anlaşılması ve tanınmasını sağlayacak gözlem, görüşme, resim analizi ve benzeri yöntemler ile farklı çalışmalar yapılabilir. Bunlarla birlikte öğretmenlere ve ebeveynlere, değer kazanımı sürecinde model olmanın öneminin anlatılabileceği eğitimlere ağırlık verilmelidir. Programda özellikle aile katılımı kısmı hazırlanırken, ebeveynlerin nasıl davranması gerektiği hususunda örneklere sıklıkla yer verilmesi önerilmektedir.

\section{Kaynakça}

Althof, W. \& Berkowitz, M. W. (2006). Moral education and character education: their relationship and roles in citizenship education. Journal of Moral Education, 35(4), 495-518.

Aydın, M. (2003). Gençliğin değer algısı: Konya örneği. Değerler Eğitimi Dergisi, $1(3), 121-144$.

Bandura, A. (1977). Social learning theory. New Jersey: Prentice-Hall.

Benazus, H. (2002). Sevginin gizemi (Ç. Erendağ, Çev.). Birinci Basım. İstanbul: Sistem.

Bilgin, N. (1995). Sosyal psikolojide yöntem ve pratik çalışmalar. İstanbul: Sistem.

Bukowski, W. M., Newcomb, A. F. \& Hartup, W. W. (1996). Friendship and its significance in childhood and adolescence: Introduction and comment. In The Company they Keep, edited by William. M. Bukowski, Andrew. F. Newcomb, and Willard. W. Hartup (p.1-15). Cambridge: Cambridge University Press. 
Çağdaş, A. (2012). Anne-baba-çocuk iletişimi (1. Bask1). Ankara: Eğiten.

Dere, H. ve Ömeroğlu, E. (2001). Okul öncesi dönemde fen doğa matematik çalışmaları. Ankara: Anı.

Deveci, H., \& Ay, T. S. (2009). İlköğretim öğrencilerinin günlüklerine göre günlük yaşamda değerler. Uluslararası Sosyal Araştırmalar Dergisi, 2(6), 167-181.

Dickert, N. W. (2009). Re-examining respect for human research participants. Kennedy Institute of Ethics Journal, 19(4), 311-338.

Fidan, N. (2012). Okulda öğrenme ve ögretme. Ankara: Pegem Akademi.

Frostig, M. \& Maslow, P. (1973). Learning problems in the classroom. New York: Grune \& Stratton.

Gay, L. R., Mills, G. E., \& Airasian, P. W. (2009). Educational research: Competencies for analysis and applications, Student Value Edition. Upper Saddle River, NJ: Merrill.

Günindi, Y. (2015). Preschool children's perceptions of the value of affection as seen in their drawings. International Electronic Journal of Elementary Education, 7(3), 371-382.

Halstead, J. M. \& Taylor, J. M. (2000). Learning and teaching about values: A review of recent research. Cambridge Journal of Education, 30(2), 169-202.

Kolukısa, E. A., Oruç, Ş., Akbaba, B. \& Dündar, H. (2008). İlköğretim sosyal bilgiler 4 ögretmen kılavuz kitabı. Ankara: Gizem.

Kurnaz, A., Çiftçi, Ü. ve Karapazar, H. (2011). Üstün zekâlı ve yetenekli öğrencilerin değer algılarının betimsel bir analizi. Değerler Eğitim Dergisi, 11(26), 185-225.

Milli Eğitim Bakanlı̆̆ (MEB). (2013). Okul öncesi eğitim programı. Ankara. Erişim adresi: https://tegm.meb.gov.tr/dosya/okuloncesi/ooproram.pdf

MEB. (2006). Okul öncesi eğitim programı (36-72 aylık çocuklar için). Ankara: Okul Öncesi Eğitimi Genel Müdürlüğü.

MEB. (2002). 36-72 aylık çocuklar için okul öncesi eğitim programı. Okul Öncesi Eğitimi Genel Müdürlügü̆, Ankara: Milli Eğitim.

MEB. (1994). Okul öncesi eğitim programı. İstanbul: Milli Eğitim.

Myers, R., G. (1992). Hayatta kalan on iki (R. A. Bakay, E. Ünlü, Çev.). İstanbul: AÇEV.

Özensel, E. (2007). Liseli kız ve erkek öğrencilerin değer yargıları ve Türk toplumunun temel toplumsal kurumlarına bakış açıları (R. Kaymakcan, S. Kenan, Ed.), Değerler ve Eğitimi içinde (s.743-769). İstanbul: DEM.

Patton, M., Q. (2014). Nitel araştırma ve değerlendirme yöntemleri. (M. Bütün ve S. B. Demir Ed. ve Çev.). Ankara: Pegem. 
Piaget, J. (1952). The origin of intelligence in children. New York: International University Press Inc.

Rokeach, M. (1979). From individual to institutional values: With special reference to the values of science. M. Rokeach (Eds.), Understanding Human Values, (p. 47-70). New York: Free Press.

Ryan, S. (2012). The conditions of kindness in politics. (Order No. 1510367, University of South Carolina). ProQuest Dissertations and Thesis, 78.

Sapsağlam, Ö. (2015). Anasınıfina devam eden çocuklara uygulanan sosyal değerler eğitimi programının sosyal beceri kazanımına etkisinin incelenmesi (Yayımlanmamış doktora tezi). Gazi Üniversitesi Eğitim Bilimleri Enstitüsü, Ankara.

Sapsağlam, Ö. (2016). Okul öncesi dönemde karakter ve değerler ĕgitimi. Ankara: Pegem Akademi.

Sapsağlam, Ö. (2017). Okul öncesi dönem çocuklarının değer algılarının çizdikleri resimler ve sözlü anlatımlarına göre incelenmesi: Sorumluluk değeri örneği. Eğitim ve Bilim, 42(189), 287-303.

Schwartz, S. H. (1994). Are there universal aspects in the structure and content of human values?. Journal of Social Issues, 50(4), 19-45.

Schwartz, S. H., \& Bilsky, W. (1987). Toward a universal psychological structure of human values. Journal of Personality and Social Psychology, 53(3), 550-562.

Such, E., \& Walker, R. (2004). Being responsible and responsible beings: Children's understanding of responsibility. Children \& Society, 18, 231-242.

Tarkoçin, S., Berktaş, D. \& Uyanık Balat, G. (2013). Okul öncesi öğretmenlerinin sınıf içi etkinliklerde çocuklarla olan iletişimlerinde kullandıkları değerlerin incelenmesi. Pegem Ĕgitim ve Öğretim Dergisi, 3(2), 37-49.

Tatlı, S., \& Güngör-Aytar, F. A. (2017). Okul öncesi dönem çocuklarının değerlere ilişkin algıları ve bunları ifade etme biçimlerinin incelenmesi. Türkiye Sosyal Araştırmalar Dergisi, 21(2), 331-354.

Tozduman-Yaralı, K., Özkan, H. K. \& Güngör Aytar, A. (2016). Yedi ve on yaş çocuklarının sevgiyi ifade ediş biçimlerinin çizdikleri resimlere yansıması. Kastamonu Eğitim Dergisi, 24(5), 2181-2194.

Trawick-Smith, J. (2014). Erken çocukluk döneminde gelişim (Çok kültürlü bir bakış açısı) (B. Akman, Ed. ve Çev.). Ankara: Nobel.

Uyanık-Balat, G. \& Balaban-Dağal, A. (2006). Okul öncesi dönemde değgerler ĕgitimi etkinlikleri. Ankara: KÖK.

Williams, R. M. (1979). "Change and Stability in Values and Value Systems: A Sociological Perspective. M. Rokeach (Eds.), Understanding Human Values, (p. 15-46). New York: Free Press. 
Yavuzer, H. (2000). Çocuk eğitimi el kitabı. İstanbul: Remzi.

Yıldırım, A. ve Şimşek, H. (2013). Sosyal bilimlerde nitel araştırma yöntemleri (9. Baskı). Ankara: Seçkin.

Yılmaz, F., Göçen, S., \& Yılmaz, F. (2013). Sokakta çalışan ve çalışmayan ilköğretim öğrencilerinin sosyal bilgiler programındaki değerlere ilişkin algıları. E-International Journal of Educational Research, 4(1), 82-99.

Yukay-Yüksel, M., Canel, N., Mutlu, N., Yılmaz, S. \& Çap, E. (2015). Okul öncesi çağdaki çocukların "iyi” ve "kötü" kavram algılarının resim analizi yöntemiyle incelenmesi. Değerler Ĕgitimi Dergisi, 13(29), 271-303.

\section{EK - 1}

\section{VERI TOPLAMA FORMU (DEĞER ANLAMLANDIRMA ENVANTERİ)}

Öğrencinin Adı Soyadı :

Uygulama Tarihi :

Doğum Tarihi

\begin{tabular}{ll}
\hline Değer & İlişkili Sorular \\
& Sorumluluk ne demektir? \\
Sorumluluk & Kimlerin sorumlulukları vardır? \\
& Senin sorumlulukların nelerdir? \\
& Sorumluluklar yerine getirilmezse ne olur? \\
& Paylaşmak ne demektir? \\
Paylaşma & Niçin paylaşılmalıdır? \\
& Neler paylaşıllabilir? \\
& Yardım etmek ne demektir? \\
Yardımseverlik & Daha önce yardım ettin mi, nasıl? \\
& Daha önce yardım aldın mı, nasıl? \\
& Saygı ne demektir? \\
& Nelere saygı duyulmalıdır? \\
Saygı & Saygısızca davranıldığında ne olur? \\
& Nazik olmak ne demektir? \\
& Niçin nazik davranılmalıdır? \\
& Nazik davranılmazsa neler olur? \\
Nezaket & Arkadaşlık ne demektir? \\
& Nelerle arkadaşlık yapılabilir? \\
& Arkadaşlar birbirine nasıl davranır? \\
& Dürüstlük ne demektir? \\
Arkadaşlık & Dürüst olmayan davranışlar nelerdir? \\
& Dürüst davranılmadı̆̆ında neler olabilir? \\
&
\end{tabular}


Extended Abstract

\section{Investigation of Preschool Children's Descriptions of Value Concepts: A Qualitative Study}

Nihat TOPAÇ, Corresponding Author, Lecturer.

Istanbul University-Cerrahpaşa, Hasan Ali Yucel Faculty of Education, Turkey.

ntopac@istanbul.edu.tr

https://orcid.org/0000-0001-9364-4072

Musa BARDAK, Lecturer.

Istanbul Sabahattin Zaim University, Faculty of Education, Turkey.

musa.bardak@izu.edu.tr

https://orcid.org/0000-0001-5585-8002

Murat KIRIŞCi, Associate Professor.

Istanbul University-Cerrahpaşa, Faculty of Medicine, Turkey.

murat.kirisci@istanbul.edu.tr

https://orcid.org/0000-0003-4938-5207

Ercan MERTOĞLU, Assistant Professor.

Marmara University, Atatürk Faculty of Education, Turkey.

ercan.mertoglu@marmara.edu.tr

https://orcid.org/0000-0002-4614-7687

Article Type: Research Article

https://doi.org/10.34234/ded. 720094

Received Date: 14.04 .2020

Accepted Date: 11.06 .2020

Published Date: 25.06.2020

\section{Introduction}

Myers (1992) stated that, to preserve the moral and social values desired by a society for the future, these values should be gained in the early stages. In addition, Uyanık-Balat \& Balaban-Dağal (2006) stated that the first achievements regarding values were obtained in the preschool period and their effects continue throughout life. From this point of view, it can be said that it is important to 
establish the foundations of values, which affect the society and are affected by society, in preschool period. Accordingly; in order to contribute to the correct definition, perception, understanding and adoption of values, which is one of the most important factors that affect human behavior from a young age, values education should be carried out systematically and in a planned manner. In this process, first, it is necessary to determine how children in early childhood perceive and define the concepts of value.

Since preschool children interact with concrete indicators before conceptual perception; in other words, because they can perceive through the sense organs, and since the concepts of value have an abstract quality while defining the concepts, different meanings and different definitions may be encountered apart from the dictionary meanings. This can be explained by Piaget's schema formation process. In this process, the imbalance created by stimuli in the mind is balanced with previous learning and experiences. (Piaget, 1952). Since the individual's understanding of the people with whom he is interacting is a matter to be considered in communication, it is important that the person uses the right vocabulary and use it correctly. Perceptions and vocabulary formed from childhood should be analyzed correctly. Based on this information, this research; put importance on containing children's verbal expressions, perceptions and analyzing them. From this point, revealing childeren's perception and definition of responsibility, sharing, benevolence, friendship, respect, honesty and courtesy, which are the subject of the research, will make important contributions to the field in terms of being a guide for subsequent research.

\section{Method}

Qualitative research method was used in this study. Gay, Mills \& Airasian (2009) emphasized that the main feature of qualitative research refers to the data collected from a small group that selected in a purposeful manner and does not contain numerical interpretation. Since it was appropriate to the subject of the study, the pattern of phenomenology (phenomenology) was used. Patton (2014) defined phenomenology as a method trying to explain an individual's perceptions of a phenomenon, with the meaning and feelings they infer from it. In this study, the facts attempted to be explained are the perceptions and definitions of preschool children about the values determined.

The study group consists of 20 children in the age group of six who attended preschool in the 2017-2018 academic year. When determining the sample, typical case sampling was used from purposeful sampling methods (Patton, 2014). 
22 questions in the total data collection tool, four for about responsibility (two for skill size) and three for other values (one for each dimension), were prepared with the opinion of the field experts.

After the interviews, the answers given by the children were evaluated by content analysis and coded and themes were created. According to Yildırım and Şimşek (2013), themes and relationships are tried to be determined by content analysis. In the basic structure of content analysis, similar elements in the data are framed with the concepts and themes created and organized and interpreted in a way that the beneficiaries can understand. These operations include four stages: coding data, creating themes, editing codes and themes, and identifying and interpreting the findings. In the content analysis process, codes and themes were created according to the answers received from children regarding each value, and the categorized themes were tabulated together with the frequency data.

\section{Findings}

In this section, the questions asked, the codes created from the answers, the themes obtained from the codes and the direct quotations are given to determine the perceptions and definitions of preschool children about the concepts of value. The answers received from the children were analyzed using the content analysis technique. Expressions close to each other among the answers received for each question were coded by writing them as items. Later, themes were constructed from these codes, then categorized and turned into tables. The number of answers given by children for each code in the tables is written in the frequency column.

"What is responsibility?" From the codes created based on the answers given by children to the question, the themes of duty, harmony, need and work have been created. More than half of the children answered, "fulfilling something," a code under the theme of Duty. A small number of children have expressed the phrase "play games", which is the code under the theme of need.

"What does share mean?" codes have been created under themes of goodness, need and freedom based on the answers given by the children to the question. Most of the children gave the answers that meant "giving to someone else", "something nice" and "sharing their toys with someone else", which coded under the theme of kindness. Some of the children used expressions that mean "having fun", coded under the theme of need. 
"What does it mean to help?" Based on the answers given by the children to this question, themes of harmony, goodness and duty were created from the codes gathered under these thesmes. Almost half of the children gave answers under the theme of harmony which coded as "to do together, to be united". The other half used expressions that meant "lifting the bit", "something nice" and "helping the mother at dinner", which constitute the codes under the theme of goodness.

Based on the answers given to the question; "What does respect mean?" themes of harmony, goodness, tolerance and respect were created from the codes gathered under these themes. Most children's' answers, which coded under the theme of harmony, were; "behave respectfully", "behave well", "not speaking badly", "speaking well" and "keeping their word". Some of the children used expressions that meant "be nice to adults" and "something beautiful", which are coded under the theme of reverence.

"What does it mean to be kind? "The themes of goodness and harmony have been created from the codes created based on the answers given by the children to this question. Most of the children gave answers which were coded under the theme of harmony, such as; "to be polite", "to be good", "to speak nice and slow", "not to be rude", "not to beat" and "to fall in love". A small number of the children used the words "behave nicely" and "share", which are codes under the theme of kindness.

"What is friendship? "The themes of goodness, need and harmony have been created from the codes created based on the answers given by children to the question. Some of the children have given answers, meaning "extending help" and "extending support," which are codes under the theme of kindness. Some of the children used the words "to play", "to love", "to have fun", "to be happy", while others used the codes under the theme of harmony, "to hold hands", "my friend", "it takes a long time" and "to get along".

"What does honesty mean? "The themes of harmony, courage and duty have been created from the codes created based on the answers given by the children to this question. Most children have given answers like; "behaving properly," "being respectful," "making peace," "friendship" and "being polite," which are coded under the theme of harmony. A few of the children used phrases that meant "not to be afraid", which was coded under the theme of courage; again a few used phrases that meant "to follow the rules", which was coded under the theme of duty. 


\section{Discussion and Conclusion}

Preschool children answered the questions about the concept of value by using another value concept instead of defining the concept or by showing an example of concrete behavior. A similar situation was observed in the study of Tatl $\&$ Güngör-Aytar (2017). After the values education given in the study, the children were asked to express the pictures made about these concepts. In five out of seven values included in this study, children's answers show that they perceive and define these concepts correctly. In two values, it is understood that the concepts are not perceived to a large extent and are perceived incorrectly. The fact that there are high number of answers such as "I don't know" in the definitions of children about honesty and courtesy values, as well as the answers that indicate they perceive the values wrongly, and show that they do not receive enough stimuli from their environment regarding these values. Possible reasons for children not seeing concrete behaviors related to these values sufficiently, and seldom encountered experiences within this context or not receiving formal values education. Having analyzed the data two months after the children started preschool education, it strengthens the idea that perceptions and definitions are family originated. However, in order to be able to speak precisely, research is needed on whether this situation is due to informal education in the family or formal education in institutions.

Eight themes have been created from the codes obtained from the responses of the participants regarding the responsibility value, such as harmony, goodness, interest, duty, need, crime-punishment, work, and caution. It can be said that these inferences are directly related to the roles and behaviors that parents reflect. It can be concluded that the instructions used in line with the responsibilities in the family are effective in the perception of the responsibility towards children.

Seven themes, namely harmony, goodness, interest, duty, need, crime-punishment, freedom, were created from the codes obtained from the responses of the participants regarding the sharing value. These conclusions may show that children's descriptions of the value of sharing are formed through metaphors and patterns' behavior, and their perceptions are correct. In addition, it can be stated that the children expressed their behaviors they had experienced in communication environments as an answer to the questions in this research.

Four themes-harmony, kindness, interest and duty-have been formed from the codes derived from participants' responses to the value of benevolence. These 
statements of children who are not enrolled in any values education program indicate that the concept is often perceived correctly. It can be said that the responses given by children stem from the adult attitudes and discourses they encounter in their daily lives. All kinds of actions and discourses carried out by an adult regarding the value of helping or charity provide the basis for children to perceive this concept in this direction. In addition, it can be said that the child has a tendency towards self-interest in his/her development period.

Eight themes have been formed: harmony, kindness, interest, duty, crime-punishment, respect, tolerance and compassion from the codes derived from the responses of the participants on the value of respect. Based on these inferences, the conclusion can be reached that children perceive the value of respect from the people with whom they interact.

From the codes obtained from the participants' responses to the value of kindness, six themes were formed: harmony, kindness, interest, duty, crime-punishment, and freedom. Many of the children are unable to define the kindness value, and some use it with false metaphors suggests that there are deficiencies or problems in perception and description. It can be said that the formation of themes such as interest, crime-punishment and freedom support this situation.

From the codes derived from the participants' answers about the value of friendship, five themes were formed: harmony, kindness, interest, need and freedom. Inferences show that children perceive and define friendship through actions they observed during the time they spend with each other. It could also be said that developmental interest and emotional needs are at the forefront.

From the codes obtained from the answers of the participants regarding the value of honesty, seven themes have been formed: harmony, kindness, interest, duty, crime-punishment, freedom and tolerance. Many of the children are unable to identify with this value, while others respond by using incorrect metaphors, indicating a lack of perception and identification or problems. The creation of themes of kindness, freedom and tolerance from answers and codes can be indicative of this situation.

The result of this study shows that, as with many concepts, children acquire their perception and description of values through environmental stimuli, life experiences, expressions used in the family and behaviors they observe in early childhood. Organizing the environment with appropriate stimuli is very important in achieving the goal establishing the desired behaviors related to values. 
This principle should be taken into consideration when creating programs and content related to values education. Studies involving researchers from different disciplines from which sources and how children's perceptions are affected should be given more space. In addition, researchers are advised to focus more on studies in which children are the participants. In addition, teachers and parents should focus on educations where the importance of being a model in the process of value acquisition can is explained. Examples of how parents should behave should be included in the program, especially when planning the family involvement section in the program. 